
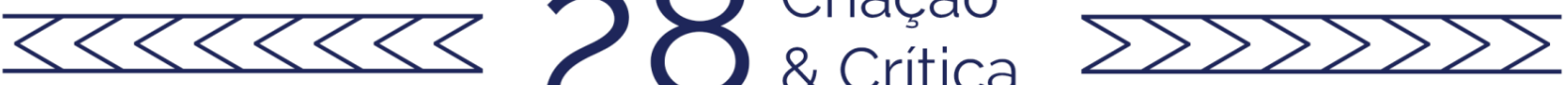

\title{
DOS DESENCONTROS AO ENCONTRO: A VIAGEM DE AlBERT CAMUS
}

\author{
AO BRASIL EM 1949
}

\author{
Samara Fernanda A. O. de Lócio e Silva Geske ${ }^{1}$ \\ "O homem, denominador comum dos povos e das raças..." \\ Antoine de Saint-Éxupery, Piloto de guerra
}

\begin{abstract}
Resumo: Em 1949, Albert Camus viajou ao nosso país para empreender uma turnê de conferências no contexto de um intercâmbio cultural entre a França e o Brasil. A leitura do Diário de viagem, composto durante sua estadia, deixa a impressão de um grande desencontro entre o escritor e os brasileiros. Tal impressão é em parte verdadeira, uma vez que natureza do intercâmbio cultural enquanto "encontro oficial" impossibilitou de certa forma um diálogo profícuo entre as partes. Por outro lado, não podemos deixar de notar que nos encontros pessoais que travou, ou por meio das ideias veiculadas em suas conferências, houve um diálogo entre Camus, seus leitores e pares brasileiros. No Brasil, a visita deixa traços nos jornais da época, bem como na lembrança e nos relatos das pessoas que o receberam. Para Camus, algumas experiências vividas no Brasil e anotadas cuidadosamente no diário são empregadas na escrita da novela "A Pedra que cresce" de $O$ Exílio e o Reino, pela qual se opera um encontro com o Brasil por intermédio da ficção.
\end{abstract}

PALAVRAS-ChAVE: Albert Camus; diário de viagem; Brasil; intercâmbio; encontro;

\section{FROM MISMATCH TO MEETING: ALBERT CAMUS'S JOURNEY TO BRAZIL IN 1949}

ABSTRACT: In 1949, Albert Camus traveled to our country to undertake a conference tour in the context of cultural interchange between France and Brazil. Reading the Travel Diary, composed during his stay, leaves the impression of a strong disagreement between the writer and Brazilians. This impression is partly truthful since the nature of the cultural interchange as an "official meeting" made it possible to a certain extent a real meeting and a fruitful dialogue between the parties. On the other hand, we cannot ignore that there was a dialogue between Camus, his readers, and Brazilian peers through the personal meetings that he held or through the ideas conveyed in his conferences. In Brazil, the newspapers of the time noticed his visit, as well as he left his trace in the memory of the people who met him. For Camus, some experiences lived in Brazil and carefully recorded in his diary are used in the writing of the short novel "The Growing Stone" of Exile and the Kingdom, through which a real encounter with Brazil operates through fiction.

KEY-wORDS: Albert Camus; trip diary; Brazil; interchange; meeting;

\section{Introdução}

O encontro está na base da experiência literária: encontro da obra com o leitor por meio da leitura; para o autor, encontro de leituras e influências que se amalgamam na

\footnotetext{
${ }^{1}$ Doutora em Letras pela Universidade de São Paulo, tradutora e especialista na obra de Albert Camus.
} 

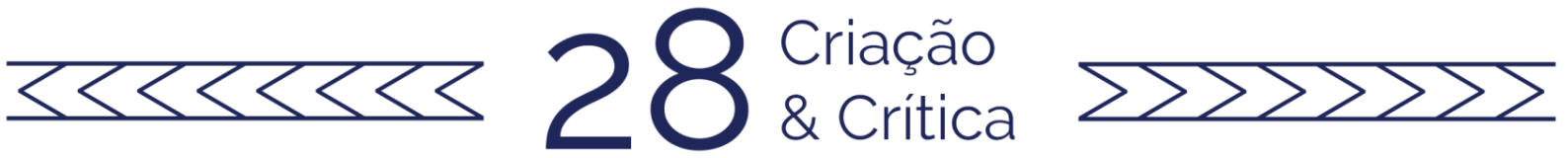

tessitura do texto literário. A literatura é, enfim, um encontro de duas "liberdades": a liberdade de oferecer ou guardar para si a obra, e a liberdade de acolhê-la ou de recusála. Em todos esses encontros, como aponta Steiner (2001), é necessário que a cortesia se faça presente e que a obra literária seja recebida como uma visita nobre e importante. Pois diante de qualquer obra de arte, quer seja ela um texto, um quadro ou uma sinfonia, somos colocados em presença de um sentido, somos convidados a "escutar" a sua linguagem a fim de compreendê-la. O verdadeiro encontro somente acontece quando ambas as partes se engajam em um diálogo, isto é, quando a compreensão se torna "responsável" (STEINER, p. 2005, 186-191).

O encontro também é, desde a virada existencial da hermenêutica, um conceitochave para a compreensão da realidade tal como a experimentamos. Assim, deixando o campo do encontro estabelecido unicamente por meio dos textos, gostaríamos de pensar acerca da experiência do encontro pessoal de um escritor com seus leitores e com seus pares. E, inversamente, como tal encontro é vivido, interpretado e assimilado posteriormente em sua obra. Ou seja, como ambas as partes se engajam em um diálogo que busca não somente ouvir e compreender o outro, mas também respondê-lo, uma vez que o encontro pressupõe sempre uma troca mútua, um intercâmbio de ideias.

E o que dizer, então, do encontro em sua forma "oficial", o intercâmbio cultural? Ele é entendido como uma troca de conhecimentos entre pessoas de diferentes culturas, uma via de mão dupla das relações entre os países, levado a cabo, na maioria das vezes, por meio de seus intelectuais e artistas. Nesse caso, não somente a cortesia, mas a acolhida hospitaleira do anfitrião e a complacência do convidado estrangeiro se revestem de grande importância para a qualidade do encontro.

Foi justamente no contexto de um intercâmbio cultural entre a França e o Brasil que o escritor Albert Camus pode encontrar-se com seus leitores e pares do outro lado do Atlântico. Depois de uma travessia de 15 dias a bordo do navio Campana que havia partido da cidade de Marselha, Camus desembarca no Rio de Janeiro no dia 15 de julho de 1949. Pequena anedota sobre sua chegada, publicada em 1949 pelo Diário de Notícias do Rio de Janeiro: conta Guilherme de Figueiredo que, ao desembarcar, o escritor havia sido perguntado pelo funcionário da aduana se ele trouxera dólares ou perfumes. Espirituoso, Camus teria apontado para sua cabeça, mostrando que essa era a única mercadoria que iria contrabandear, em clara referência ao intercâmbio cultural a serviço do qual viera ${ }^{2}$. Convidado pelo governo francês, o escritor empreendeu uma turnê de conferências por diversas cidades brasileiras.

O acordo de intercâmbio cultural entre ambos os países, assinado em 1948, estipulava, além da livre circulação de livros, revistas e filmes entre ambos os países, a visita de intelectuais, artistas e professores ${ }^{3}$. Tal acordo fora anunciado pelos jornais da

\footnotetext{
${ }^{2}$ CAMUS encontra o absurdo. Diário de Notícias. Rio de Janeiro, 07 ag. 1949.

3 "I. Accord culturel entre la France et le Brésil (6 décembre 1948)" Cf. CARDOSO; MARTINIERE, 1989, p. 307-310 e PEREIRA, 2009, p.56
} 

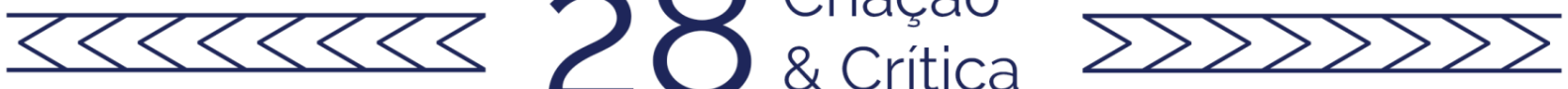

época como um dos maiores já estabelecidos entre a França e o Brasil ${ }^{4}$ e previa a visita de grandes personalidades culturais francesas aguardadas com expectativa pela intelectualidade brasileira. Esse intercâmbio oficializa uma colaboração já em marcha representada, por exemplo, pela chamada "missão francesa" que enviara professores e intelectuais de renome para colaborar no desenvolvimento da ainda jovem academia brasileira. Entre eles, podemos citar os nomes de Roger Bastide, Fernand Braudel, Claude Lévi-Strauss e Lucien Febvre, historiador que empreendeu uma de suas viagens ao Brasil na mesma época que Camus e se refere a essa cooperação como um casamento, no qual a França, um senhor idoso, esposa alguém muito jovem, o Brasil (FEBVRE, 1950).

No entanto, o encontro entre Camus e o Brasil esteve longe de poder ser considerado uma união feliz. Jean-Louis Andreu (1992), um dos primeiros a se debruçar sobre o tema, classifica a viagem como um "encontro fracassado", devido a causas de múltiplas ordens, tanto culturais e políticas (no sentido amplo do termo), quanto às circunstâncias pessoais do escritor. Mario Carelli (1993), refletindo especificamente sobre o intercâmbio cultural entre a França e o Brasil, identifica tal fracasso como efeito da "impermeabilidade" do escritor à realidade brasileira. Regis Tettamanzi (2004), em uma perspectiva mais positiva, aponta que se quisermos realmente avaliar a viagem de Camus, devemos tornar nossos olhos não apenas para - Diário de viagem, mas para o aproveitamento dessas experiências na escrita da "Pedra que cresce", última novela de O Exílio e o Reino, em que se operaria uma passagem do "Brasil enfermo" para o "Brasil fraterno".

Graças a publicação de seu Diário de viagem, em 1978, podemos acompanhar os detalhes de sua visita ao país, seu estado de ânimo, suas impressões sobre nossa terra, assim como depreender preciosas pistas sobre as pessoas com as quais se encontra. Mas é também por meio dele que se constata todo o descontentamento do escritor em relação à sua estadia. Além do diário de viagem, a visita também deixa traços nos jornais da época, assim como na lembrança e nos relatos das pessoas que o receberam.

Foi Augusto Frederico Schmidt quem guardou a mais amarga recordação do encontro com Camus, que deve ser considerado, na verdade, como um grande desencontro, tamanho foi o mal-entendido entre eles. Ambos jantam na primeira noite de Camus no Brasil, mas os modos de Schimidt e seus companheiros são tão grosseiros, que o escritor considera até mesmo deixar o restaurante, conforme relata em seu diário. Em seu necrológio, o poeta relembra as horas que passaram juntos e reconhece o quanto foram penosas para os dois. A lembrança que ele guardara do escritor se resume a uma impressão de dureza e de implacabilidade, mas conclui, condescendente, de que possivelmente tenha se enganado (SCHMIDT, 1964, p.107-110). Camus, por sua vez, tece em seu diário uma descrição desse que beira a caricatura, testemunhando sua grande antipatia.

\footnotetext{
${ }^{4}$ MAIOR intercâmbio cultural entre o Brasil e a França. A manhã. Rio de Janeiro, 17 jun. 1949.
} 

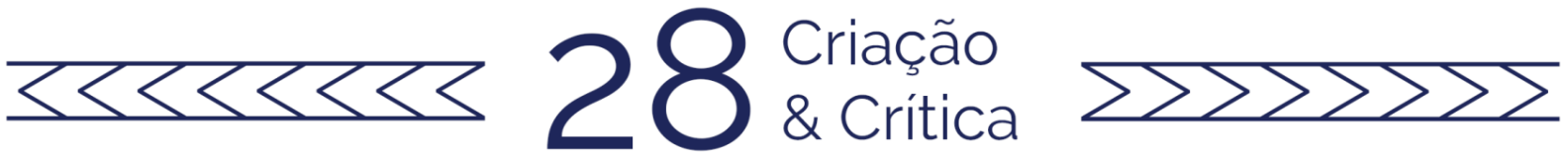

De fato, o Diário de viagem lido à luz de todos os testemunhos da época aos quais podemos ter acesso deixa realmente a impressão geral de um grande desencontro cujas causas são claras: de um lado, o diário apresenta o cansaço e o estado de saúde debilitado de Camus, de outro, os jornais e os relatos mostram a exagerada hospitalidade com que é recebido por alguns, além do excesso de atividades ao qual é submetido. Esses fatores parecem ter se aliado tragicamente: no diário, profundamente debilitado por conta de uma gripe, Camus queixa-se da insensibilidade e da histeria de seus anfitriões. Sua aversão é tal que, no retorno à França, o escritor resume ao amigo Jean Grenier o saldo negativo de tal viagem da seguinte forma: "Sinto uma indigestão de humanidade" (CAMUS; GRENIER, 1981, p.164). As sequelas são também físicas, pois a viagem é ainda a ocasião de uma recaída da tuberculose que o obriga, ao voltar para casa, a passar dois meses nos Alpes para se recuperar.

Por meio do cotejamento de todos esses documentos tentaremos, neste artigo, traçar duas linhas de leitura da viagem de Camus ao Brasil: primeiramente a do desencontro e, em seguida, a do encontro. Em primeiro lugar, tentaremos entender as causas que fizeram surgir a impressão desse desencontro e mostrar em que medida a própria natureza do intercâmbio cultural entendido como "encontro oficial" impossibilita, sob alguns aspectos, um verdadeiro encontro e um diálogo profícuo entre as partes. Em um segundo momento, gostaríamos de mostrar que, apesar de tudo, no diálogo pessoal de Camus com o Brasil, seja nos encontros pessoais que travou, ou por meio das ideias veiculadas em suas conferências, tanto o escritor quanto seus pares e leitores brasileiros são transformados. Do lado de Camus, algumas experiências vividas na viagem ao Brasil e anotadas cuidadosamente no diário são empregadas no processo de escrita da "A Pedra que cresce". Do nosso lado, graças a sua visita, abre-se uma nova fase da história da recepção camusiana ${ }^{5}$.

\section{Intercâmbio cultural: (des)encontros oficiais}

\subsection{As circunstâncias do encontro}

Camus recebera a proposta para visitar a América do Sul ainda em 1948, pouco tempo depois do estabelecimento do acordo de intercâmbio, do então diretor geral das relações culturais francesas, Roger Seydoux. Ele aceita o convite e sugere, em carta datada de 8 de dezembro de 1948 (TODD, 1996, p. 686), duas conferências, uma sobre a

\footnotetext{
${ }^{5}$ Cf. o trabalho de conclusão de curso de BARBIERI, 2017: "O filósofo do absurdo nos trópicos: a recepção inicial da obra de Albert Camus no Brasil a partir dos periódicos nacionais da década de 1940" que indica que a visita do escritor em 1949, seguida da publicação da primeira tradução de uma obra sua em 1950, demarcariam uma nova etapa na recepção do autor. Para demonstrar tal fato, o pesquisador mostra que até 1945 não há nenhuma referência ao nome do escritor nos periódicos nacionais e que entre 1945 e 1946 ele pode repertoriar apenas 9 artigos. A partir de 1947, data de publicação de $A$ Peste, os artigos multiplicamse, sobretudo em 1949, quando ultrapassam a marca dos 50 textos.
} 

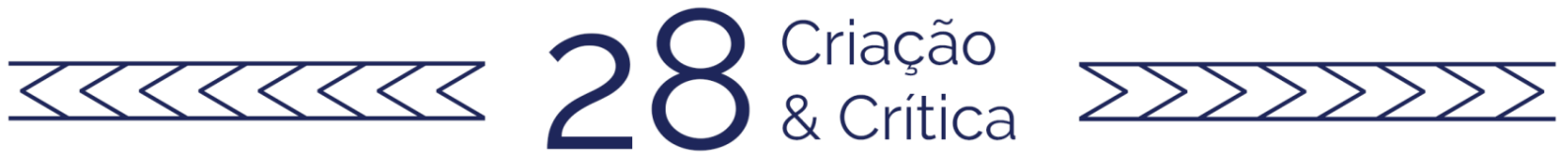

crise espiritual do mundo contemporâneo (Les embarras de la violence ou Nous autres meurtriers) e uma conferência literária intitulada "Romance e revolta", temas sobres os quais estava refletindo naquela época e que serão abordados posteriormente em 0 Homem Revoltado, publicado em 1951.

Em janeiro de 1949, Gabrielle Mineur, adida cultural da Embaixada da França no Brasil, trava contato com Camus a fim de organizar sua viagem. O escritor expressa seu desejo de não ter que falar muito e de evitar ao máximo as manifestações oficiais (CAMUS, 2013). Como veremos, ocorrerá o extremo oposto.

Seu desembarque é descrito como um "turbilhão" que começa mesmo antes que ele coloque os pés em terra, pois jornalistas haviam subido a bordo 6 e a foto publicada no respectivo artigo não deixa desmentir o afã dos jornalistas. Tal turbilhão o acompanhará durante toda a sua estadia, com raros momentos de descanso, o que é ainda mais agravado por um estado depressivo que começa a se desenhar já durante a travessia marítima. Uma entrada do diário dois dias antes de sua chegada já anuncia um estado de ânimo pouco propício para encarar tal viagem, quando escreve que desejava evitar a face humana. Tal estado chega ao seu ápice quando constata, já no fim de sua estadia, que desejava morrer.

No seu primeiro dia no Brasil, já repleto de atividades, Camus promete recusar o que for indispensável a partir do dia seguinte. Mas 15 dias depois constatará amargamente que tudo o que recusara durante toda a vida com obstinação, aceita aqui como se tivesse antecipadamente consentido em tudo nessa viagem que não havia desejado. A sua visita se revelará, como ele mesmo constata em carta, um "rodeo extenuante" (CAMUS; GRENIER, 1981, p.164). Tal impressão de cansaço se explica pelo fato de que em pouco mais de um mês ele percorre o continente americano de norte a sul. Além do Rio de Janeiro, visita Duque de Caxias e Teresópolis, antes de partir para São Paulo e Iguape. Prossegue a viagem a Recife, Salvador e Porto Alegre, onde permanece até o dia 10 de agosto, de onde parte para o Uruguai, Argentina e Chile, retornando ao Brasil para, enfim, retornar à França.

O excesso de atividades, assim, pode ser contado como uma das primeiras e possíveis causas para o patente descontentamento de Camus em relação à sua viagem. André Maurois, que visitara o país em agosto de 1947, é também pego por esse turbilhão, chegando a proferir quatro conferências em um só dia, mas deixa o Brasil, conforme relata, "morto de cansaço, mas contente" (1948, p. 67).

Ainda no diário, Camus evoca a ideia de "calvário" para classificar sua passagem pelo país. O fato é que, no Brasil, conhece pessoas, profere conferências, concede entrevistas, visita pontos turísticos, mas tem certeza quanto a estar cumprindo bem a função para qual foi designado, como declara em carta a Michel e Janine Gallimard (TODD, 1996 p. 692). O que nos leva a nos perguntarmos sobre o verdadeiro significado

\footnotetext{
${ }^{6}$ ALBERT Camus fala sobre o existencialismo. Gazeta de Notícias. 16 jul. 1949.
} 

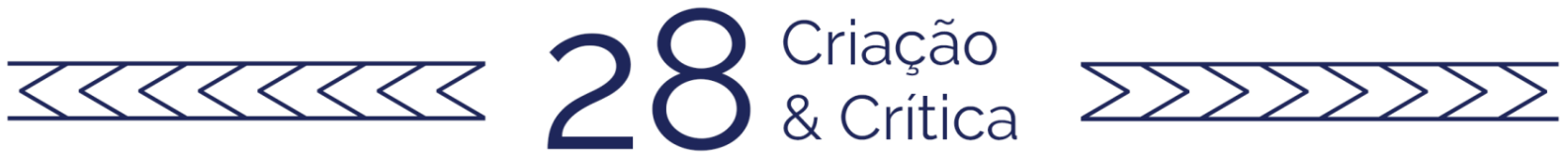

de um intercâmbio cultural e quais são as condições para que o encontro, em seu aspecto oficial, possa ser realmente enriquecedor para ambas as partes.

\subsection{Por que Camus?}

Os motivos pelos quais Camus fora convidado pelo governo francês para empreender tal intercâmbio ainda não foram elucidados, mas em nosso país ele é visto como um "legítimo embaixador de tudo o que a França tem de melhor e duradouro". 7

A jornalista Leda Barreto, escrevendo para o jornal "A manhã", começa seu artigo por uma contextualização dessa importante visita ao discorrer sobre a importância de um intercâmbio de homens e ideias, especificamente nos campos da cultura e da arte. Esse tipo de intercâmbio cultural acompanha a ação da diplomacia ou dos interesses econômicos e contribuiria para o estreitamento das relações entre os povos. Em primeiro lugar, França e Brasil, segundo a jornalista, compartilham laços de latinidades; mais do que isso, são dois países que se completam, pois possuem tendências e aspirações comuns "no processo das grandes causas universais". E são essas causas, exatamente, que fazem toda a notoriedade de Camus em nossas terras. Para Erico Veríssimo, que o saúda com um discurso antes de uma conferência proferida em Porto Alegre, o escritor é "uma das mais claras, mais belas e corajosas vozes da França de hoje, temperada na forja da Resistência". Para Murilo Mendes, Camus é "uma testemunha extremamente sensível do drama da nossa época"9, pois não é um intelectual de gabinete, por conta de sua atuação na clandestinidade do movimento da Resistência

Depois da publicação de $A$ Peste em 1947 e do papel desempenhado na Resistência francesa, Camus era considerado um escritor consagrado e um intelectual respeitado. É exatamente assim que é apresentado ao público brasileiro em um artigo intitulado "Quem é Albert Camus?"10 publicado poucos dias antes de seu desembarque.

Ele parece bastante consciente de sua notoriedade e do papel que vem desempenhar, mas não sem ironia, o que pode ser notado quando transcreve em seu Diário de viagem as seguintes palavras aduladoras proferidas por um certo "señorito": "Todo o Brasil me espera febrilmente. Minha vinda a este país é a coisa mais importante que aconteceu depois de um número considerável de anos. Aqui eu sou tão famoso quanto Proust..." (CAMUS, 2004, p.66).

Tão famoso quanto Proust, mas não tão importante quanto Sartre... Camus é considerado em nossas terras como um filósofo existencialista, o segundo, depois de Sartre, evidentemente... Imagem que o escritor apressa-se em desfazer, mas em vão,

\footnotetext{
7 "A CONFERENCIA de Albert Camus." Correio do Povo. 19 ag. 1949.

${ }^{8}$ BARRETO, Leda. 'Um missionário da paz". A Manhã. Rio de Janeiro, 21 ag. 1949, p.3.

${ }^{9}$ MENDES, Murilo. "Camus". Letras e Artes, Suplemento de A Manhã. Rio de Janeiro, 7 ag. 1949 , p. 5

10 "QUEM é Albert Camus?". Letras e Artes, Suplemento de A Manhã. Rio de Janeiro, 10 jul. 1949 , p.13 e 14.
} 

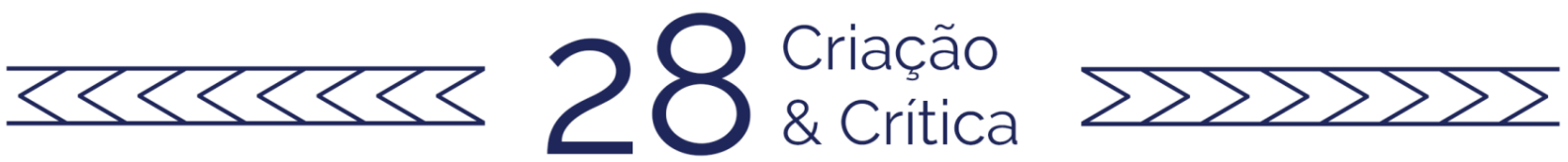

pois os jornais continuam a apresentá-lo dessa forma ${ }^{11}$. Salvo alguns jornalistas, cuja cultura francesa é profunda e o conhecimento da obra de Camus permite tecer análises mais justas ao seu pensamento.

É o caso, por exemplo, do artigo de Luiza Barreto Leite que reflete sobre a proeminência da França em termos culturais, e sobre Camus, cuja visita é justificada não somente por sua patente notoriedade, mas pela tradição da qual faz parte e a qual representa, a do "espírito francês". E é exatamente esse "espírito" que a política cultural francesa da época, ao assinar acordo de intercâmbio parece pretender propagar. A opinião de que a França tinha supremacia, no aspecto cultural, sobre outros países é moeda corrente na primeira metade do século $\mathrm{XX}^{12}$.

Conclui, porém, a jornalista, que Camus não vem falar somente em nome da França, mas em nome da Europa e do mundo. E admoesta os leitores para que esses não somente encontrem Camus por meio de suas obras, mas por meio de um diálogo vivo e pessoal. Ouvir um escritor pessoalmente, eis o privilégio oferecido por um intercâmbio cultural, pois tal encontro promove outro tipo de percepção e de relação com a sua obra, é o que nota Leite quando percebe entre Camus "o ser humano" e Camus, o pensador, uma consonância entre seus gestos, atitudes e as suas ideias. ${ }^{13}$ É o que não deixa de notar também Otto Maria Carpaux: "O contato pessoal com um grande escritor pode ser quase tão importante como a leitura de seus livros. Esse argumento já serve para justificar as atividades dos adidos culturais das Embaixadas convidando escritores como Albert Camus para visitar o Brasil." (1951, p.174-175)

\subsection{Nossa exagerada hospitalidade...}

Mas o intercâmbio cultural "vira negócio contraproducente quando cai nas mãos de pessoas que ignoram as condições mais elementares", o que ocorreu nesse caso, sem dúvidas, segundo Carpaux. Quais seriam essas condições básicas? Uma boa organização por parte dos responsáveis e uma acolhida hospitaleira dos anfitriões, podemos dizer.

No que se refere à primeira condição, a impressão que se tem a partir da leitura dos jornais é que o adido cultural apenas se encarregou de organizar a estadia de Camus

\footnotetext{
11 Camus oferecera a mesma resposta a diversos jornalistas, a saber, que o existencialismo era uma filosofia como qualquer outra e que não poderia discorrer sobre o assunto rapidamente. Ele não deixara de reiterar, porém, que não se sentia um existencialista, pois sua formação moral era sobretudo influenciada pelos filósofos gregos. Cf., por exemplo, JEAN, Yvonne. "Com Albert Camus". Correio da Manhã. Rio de Janeiro, 20 jul.1949, p.1 e 3.

${ }^{12}$ Cf. TETTAMANZI, 2004. p. 86-87 que reporta as palavras do diplomata Charles Wiener, escritas em 1907: "On tient ici pour vérité générale qu'en passant par le cerveau français, la pensée humaine se transforme et se bonifie comme l'eau se change en vin clair et généreux lorsqu'elle filtre a travers les ceps et raisins de France. Les Brésiliens le savent si bien qu'ils demandent leur savoir au livre français. C'est qu'ils sont et qu'ils veulent rester latins dans cette Amérique Latine."

${ }^{13}$ LEITE, Luiza Barreto. "Albert Camus - o ser humano". Letras e Artes, Suplemento de A Manhã. 24 jul. 1949. p. 4
} 

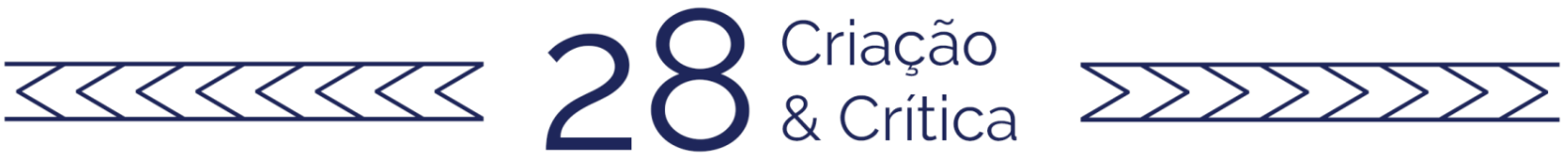

em seus aspectos gerais (cidades a serem visitadas, conferências a serem proferidas, encontros oficiais), deixando a cargo de cada cidade que o receberia, representada por associações culturais França-Brasil, a organização mais detalhada de suas atividades paralelas. Com respeito a segunda, podemos dizer que seus anfitriões exerceram uma exagerada hospitalidade, como mostra Carpaux em um lamentável resumo do que fora a visita de Camus ao Rio:

Um dos escritores mais sérios do nosso tempo foi arrastado pelas 'boites' de Copacabana, pelos salões da granfinagem, por 'salas de discussões' em que repórteres, disfarçados de estudantes, Ihe dirigiam perguntas de entrevista; iludiam-no com macumba habilmente encenada. (CARPAUX, 1951, p. 174-175)

A percepção do crítico é veraz, uma vez que o escritor deixa claro em seu diário que nada o irrita mais do que certas mundanidades e o encontro de diversas pessoas, pois fisicamente não consegue suportar uma sociedade numerosa. Acrescente-se a isso a falta de sensibilidade de seus anfitriões que parecem não perceber o cansaço de Camus, ainda mais agravado por uma forte gripe.

Em seu discurso de abertura à conferência de Camus, Erico Veríssimo parece adivinhar (ou o sabia, de fato) o que fora até então a estadia do escritor francês quando chegara a Porto Alegre:

Adivinho e compreendo, senhor Camus, todo o pavor e as apreensões que se apoderam de um homem reservado e discreto quando ele empreende uma longa viagem de conferências através dos diferentes países da América do Sul; ele corre o risco de ser flagelado a cada instante por discursos, por recepções com banda de música na frente, por abraços calorosos e, sobretudo, por perguntas um tanto indiscretas ${ }^{14}$.

Camus conheceu no Brasil os maiores intelectuais e escritores da época, mas que pertenciam a grupos diversos, havia os de São Paulo, os do Rio, os do Recife (SAUTHIER, 2014, p. 498). Tais intelectuais já estavam habituados a receber e a ciceronear os visitantes estrangeiros. Mas a visita de Camus acaba se transformando em verdadeira disputa entre os grupos de intelectuais para ver quem era capaz de agradar mais, como deixa entrever o "recado" do paulistano Oswald de Andrade, aos seus amigos cariocas.

A embaixada da França está retendo demasiadamente o grande autor do Mythe de Sisyphe em suas malhas diplomáticas e sociais. A natureza do Rio, espécie de cartão de visita do país, não pode satisfazer a solidão de Camus, ávida de geografia e de povo. Aqui em São Paulo quando ele vier, poderíamos talvez apresentar-Ihe uma das festas folclóricas do começo de agosto, onde ele conheceria esse Brasil sem máscara onde o assombro, a

\footnotetext{
14 Transcrição do discurso de abertura em Letras \& Livros, Suplemento do Correio do Povo. Porto Alegre, 15 de ag. de 1981.
} 

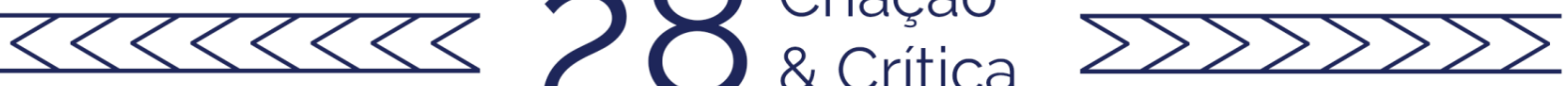

alucinação e o milagre fazem as coordenadas do maravilhoso. Camus precisa ver o que há por detrás das montanhas que emparedam a capital asfaltada. E o clima de absurdo que é o clima de sua obra, encontraria o apoio de nossas florestas sensacionais, de nossos rios sem destino, de nossa gente pré-histórica. A parte intelectual e culta de São Paulo também o espera para ouvir sua grande palavra. ${ }^{15}$

As palavras de Oswald se revelarão, sob alguns aspectos, profundamente verdadeiras, uma vez que foi a visita a "uma dessas festas do começo de agosto", a saber a 'Festa do Bom Jesus' na cidade de Iguape, que Camus recupera em sua novela "A Pedra que cresce" de $O$ Exílio e o Reino. O que mostra que nas mútuas trocas que pressupõe todo intercâmbio cultural, o Brasil ofereceu material para o trabalho literário do escritor, assunto ao qual retornaremos neste artigo.

Em resposta a Oswald, o suplemento Letras e Artes, do Jornal carioca A Manhã, descreve a passagem de Camus por São Paulo, ciceroneada pelo poeta, com um tom irônico:

Camus passou uma semana em S. Paulo. Do programa organizado em sua honra pelo empresário Oswald de Andrade constou: visita à Penitenciária do Estado, visita a uma estação de rádio (onde o visitante foi obrigado a ouvir um dos programas radiofônicos mais cacetes que existem, organizado pelo speaker-poeta-e-vereador Cid Franco), visita a Iguape (no interior do Estado), para assistir às tradicionais festas do Divino. E uma feijoada em casa do aludido empresário. Certamente outras pessoas se incutiram de proporcionar ao autor de "La Peste" homenagens menos chatas, mais interessantes e à altura de sua inteligência, mas destas o reportes não teve notícia. ${ }^{16}$

Diante das circunstâncias aqui evocadas por conta de um suposto excesso de hospitalidade, perguntamo-nos se o que ocorreu foi realmente um intercâmbio de ideias, um encontro profícuo entre intelectuais de ambos os continentes.

\subsection{Nosso complexo colonial...}

Segundo alguns jornalistas, esse intercâmbio, que pressupõe trocas mútuas, seria impossível devido ao "complexo colonial"17 de nossa intelectualidade diante do ilustre

\footnotetext{
${ }^{15}$ ANDRADE, Oswald de. "Telefonema". Correio da Manhã. 26 jul. 1949, p. 2.

${ }^{16}$ SILVEIRA, Alcantara Silveira. Coluna "S. Paulo nas Letras e nas Artes" Letras e Artes, Suplemento de A Manhã. 14 ag. 1949, p. 10.

17 Sobre nosso "complexo" - num artigo da Gazeta de Notícia de 10 de junho de 1949 que anuncia para breve a visita de Camus entre outros intelectuais- o articulista encara o intercâmbio cultural como uma mera oportunidade de promoção pessoal por parte dos escritores: "Desejamos dar boa as vindas a todos eles, mesmo em sabendo que vem conquistar público e mais publicidade, mas neste ensejo, que nos vejam realmente com bom senso, compreendam nossas peculiaridades e falem de nós com justiça e interesse e não como uma nação perdida no mapa-mundi, pois não somos e não seremos nunca. "
} 

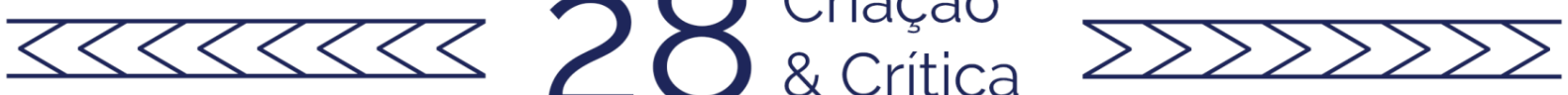

visitante europeu. Essa opinião é veiculada, por exemplo, em um artigo sobre "Camus e a situação do escritor brasileiro", cujo trecho, de tom bastante mordaz, transcrevemos:

O brasileiro há de ser sempre um eterno embasbacado diante da Europa. $\mathrm{Na}$ verdade, continuamos, como os índios da primeira missa, acocorados e pasmados em face dos estrangeiros que nos visitam. Ainda agora com a rápida excursão do sr. Albert Camus a São Paulo, repetiu-se o que se viu há anos, quando da visita do sr. Roger Calliois. Que sejamos amáveis e hospitaleiros, está certo. Que tivéssemos demonstrado a Camus nossa admiração pelo escritor e nosso carinho pelo homem da "Resistência", certíssimo. Mas que tivéssemos inagurado essa espécie de "semana Camus", com briguinhas de namorados, porque "Fulano quer monopolizar Camus sem deixar nem um tiquinho pra gente"; que nos exibiremos em ciumezinhos e despeitozinhos de aldeia e nesse delirante desejo de conversar com Camus, pegar no braço de Camus, convidar Camus para almoçar, segurar o chapéu de Camus enquanto ele faz conferência - eis o que é ridículo e nos reintegra, não obstante a altura de nossos arranhacéus, na nossa verdadeira mentalidade semi-colonial e botocuda, incapaz de independência econômica e de autonomia intelectual. O mais irritante, porém, é que muitos dos participantes do "festival Camus" mal conheciam a obra do escritor francês e naturalmente, às vésperas de sua chegada, apressaram-se a correr às livrarias na ânsia de adquirir seus livros. ${ }^{18}$

A antropofagia cultural, proposta por Oswald de Andrade, pretendia oferecer uma solução a esse complexo diante do europeu, pois seu objetivo não era rejeitar a cultura do outro, nem tampouco a ela se submeter. Ao contrário, ele propunha que "engolíssemos" simbolicamente a cultura dos outros, a fim de criar uma cultura brasileira original. Teoria que Oswald expõe a Camus - "a antropafagia como visão de mundo" - e que parece ter chamado a sua atenção, pois figura em todas as dedicatórias que escreve para o poeta ${ }^{19}$.

Mas é interessante observar que exatamente no momento em que os modernistas, tendo Oswald como seu cabeça-de-ponte, reagem contra os modelos europeus, nesse intercâmbio cultural, eles parecem agir, como evoca bastante escandalosamente Abel Bonnard ${ }^{20}$, como primitivos - termo que o poeta modernista gostava de empregar - que mostram aos franceses os tesouros de seu solo e, em troca,

\footnotetext{
${ }^{18}$ MARTINS, Luis. "Camus e a situação do escritor brasileiro". O Estado de São Paulo. 16 ag. 1949. p. 8

${ }^{19} \mathrm{Em}$ um exemplar de Le Malentendu/Caligula : "à Oswald de Andrade qui unit les raffinements des grands européens au cœur vrai de ses chers primitifs/ son confrère et son ami/Albert Camus" ; e Les Justes: "à Oswald de Andrade, cette histoire d'anthropophagie/ en souvenir fidèle des beaux jours d'Iguape/et avec l'amitié des cannibales/Albert Camus." Fundo Oswald de Andrade, CEDAE/UNICAMP

20 "On est touché de voir avec quel empressement les Brésiliens accueillent les Français qui leur paraissaient répondre à l'avidité de leurs intelligences. II nous montrent les trésors de leur sol et nous demandent ceux de notre culture. Cela rappelle la franchise et la naïveté des anciens échanges: ils nous offrent des papillons et nous demandent des idées." (BONNARD, 1929, p. 52)
} 

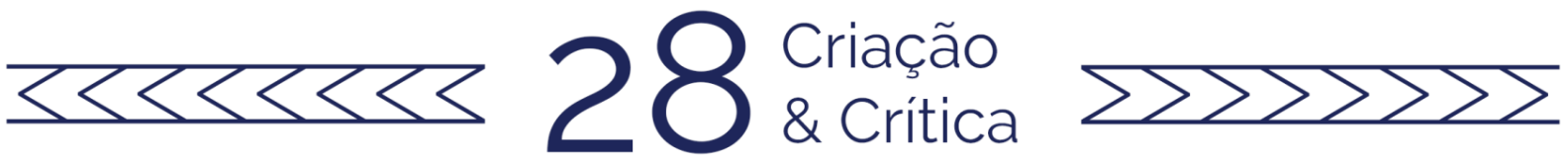

recebem cultura vinda da França ${ }^{21}$. Além dos passeios em pontos turísticos do $\mathrm{Rio}^{22}$, de São Paulo, do Recife, alguns de seus anfitriões brasileiros se apressam em mostrar todo nosso "exotismo", o aspecto "pitoresco" de nossas paisagem, o que consideram agradar certamente ao visitante europeu.

$\mathrm{Na}$ verdade, o pitoresco de nossas paisagens parece the causar certo estranhamento, como pode ser depreendido de certos epítetos dados ao nosso país ao longo do Diário de viagem como "terra imensa, que tem a tristeza dos grandes espaços" ou ainda desta impressão geral sobre o país:

[...] olho para esta natureza monótona e estes espaços imensos; não se pode dizer que sejam belos, mas colam-se à alma de uma forma insistente. País em que as estações se confundem umas com as outras; onde a vegetação inextricável torna-se disforme; onde os sangues misturam-se a tal ponto que a alma perdeu seus limites. Um marulhar pesado, a luz esverdeada das florestas, o verniz de poeira vermelha que cobre todas as coisas, o tempo que se derrete, a lentidão da vida rural, a excitação breve e insensata das grandes cidades - é o país da indiferença e da exaltação. (CAMUS, 2004, p.132-133)

A leitura do Diário de viagem permite também entrever que Camus procura fugir dos clichês tão comuns na descrição da paisagem e dos costumes do povo brasileiro³; seus anfitriões, ao contrário, são incansáveis na tarefa de lhe apresentar todas as manifestações culturais e religiosas do país. O escritor visita terreiros de macumba e de candomblé no Rio, acompanha uma procissão em lguape, assiste à apresentações de bumba-meu-boi e de maracatu no Recife.

Sobre esse espetáculo popular, conta um jornalista do Diário de Pernambuco, que após tê-lo assistido, Camus ficara impressionado e não parava de repetir: "É extraordinário, é memorável", pois tinha vindo ao Brasil exatamente por essa razão, e não somente para ver avenidas e arranha-céus ${ }^{24}$. De fato, em São Paulo, ele havia visitado o

\footnotetext{
${ }^{21}$ Para mais nuances acerca da questão cf. DA COSTA, 1991,161-170. Um dos primeiros artigos escritos depois que Camus chega ao Brasil, contextualiza a visita do escritor no interior do intercâmbio cultural Brasil/França ressaltando que o nosso país também enviaria seus intelectuais e artistas para a Europa, mas parece esposar tal perspectiva quando apresenta a observação de certo historiador e sociólogo para quem "os europeus tem para nos dar os ensinamentos de sua vasta cultura acumulada e que nós, em troca, temos para oferecer-lhes o exemplo das nossas descobertas, realizações e audácias." In: "Precisamos conquistar a paz e não esperar que a encontremos entre os presentes de ano novo" Gazeta de Notícias. 20 jul. 1949.

${ }^{22}$ Cf. as fotos publicadas em TANASE, p.184 e CAMUS, 2010. p. 121 que mostram o escritor em pontos turísticos do Rio de Janeiro.

${ }^{23}$ Sobre o Rio, escreve: "E vemos as luzes do Rio correndo ao longo da costa, o 'Pão de Açúcar', com quatro luzes no seu topo, e no mais alto cume das montanhas, que parecem esmagar a cidade, um imenso e lamentável Cristo luminoso". (CAMUS, 2004, p. 61) Para uma análise mais aprofundada, cf. TETTAMANZI, 2004, p. 269-270.

24 "UM ESPETÁCULO tipicamente popular para Albert Camus". Diário de Pernambuco, 23 jul. 1949, p.3. Nas fotos que ilustram a notícia é possível ver Camus sentado em uma cadeira enquanto assiste ao espetáculo.
} 

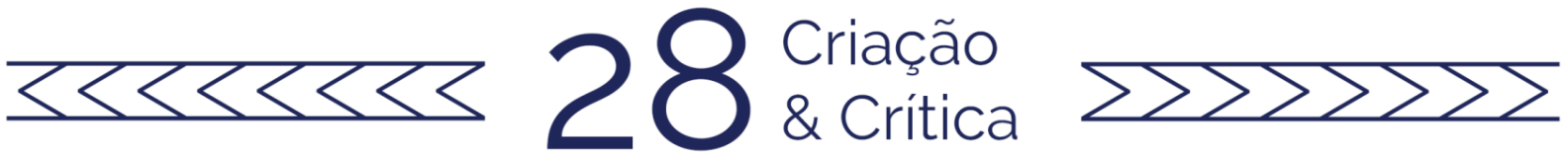

famoso edifício Itália e asseverado sobre a capital: "Cidade estranha, Oran desmedida" (CAMUS, 2004, p.97)

Camus aprecia particularmente essa visita a Recife e a Olinda, como revela no Diário de viagem, e se compararmos a entrada de 22 de julho a uma notícia da época ${ }^{25}$, podemos constatar o quanto cada uma, ao apresentar seu ponto de vista particular, dialogam e se completam. Ele ficara realmente encantado com as igrejas e com o pátio do convento de São Francisco e classifica o bumba-meu-boi como um "espetáculo extraordinário".

E foi durante esse passeio pelas ruas da cidade que uma simples apreciação sua deu origem, em resposta, a um número inteiro da Revista Nordeste ${ }^{26}$. Relata Aderbal Jurema, em seu editorial, que o escritor teria ficado surpreso ao descobrir que Proust fosse tão conhecido no Brasil e especialmente em Pernambuco. Os intelectuais recifenses parecem interpretar tal surpresa como um indício de que Camus consideravaos provincianos. Assim, em um número todo dedicado a Proust e cujo subtítulo era "Em busca da província perdida", Jurema ressalta a "universalidade de Proust e a possibilidade, para um nordestino, um parisiense ou um carioca, encontrar, da mesma maneira, o tempo perdido." (SAUTHIER, 2014, p. 413) Certamente Camus não estaria em desacordo com tal ideia, uma vez que, em seu último romance, ele também se apropria da empreitada proustiana para rememorar a sua infância pobre na Argélia, que na época era uma colônia francesa ${ }^{27}$.

Como podemos constatar, o olhar de Camus sobre o Brasil varia entre a curiosidade, o interesse, o enfado e o estranhamento, mas não se pode dizer, entretanto, que se trata de um olhar de um europeu sobre o "novo mundo". Como podemos notar ao longo do diário, o escritor utiliza como medida de comparação do Brasil a Argélia, não a França. Parece não haver, dessa forma, uma sintonia entre ele e seus anfitriões, talvez pelo desconhecimento de que Camus não era um francês de Paris: nascido na África, em um país também banhado pelo sol e pelo mar, crescera correndo pelas ruas do bairro pobre de Belcourt, em Alger.

\subsection{A língua: do mal-entendido à compreensão}

Em uma entrada do diário, Camus anota curioso os dizeres de um cartaz afixado no hotel no qual se hospeda em Salvador: "Todo o Brasil fala francês". De fato, conhecendo muito pouco inglês e arriscando-se no espanhol, ele se comunica com os brasileiros essencialmente em sua própria língua. Somos, dessa maneira, colocados

\footnotetext{
25 "CAMUS amaria ficar no Recife só por causa do pateo de São Pedro". Diário de Pernambuco, 22 jul. 1949.

${ }^{26}$ Nordeste, Recife: ano IV, n5, novembro-dezembro 1949

${ }^{27}$ Cf. Geske, Samara "Camus, le Proust des pauvres" em La rosée sur les ruines: une lecture du processus de création du roman inachevé Le Premier Homme d'Albert Camus Tese de doutorado, Universidade de São Paulo, 2016, p. 273.
} 

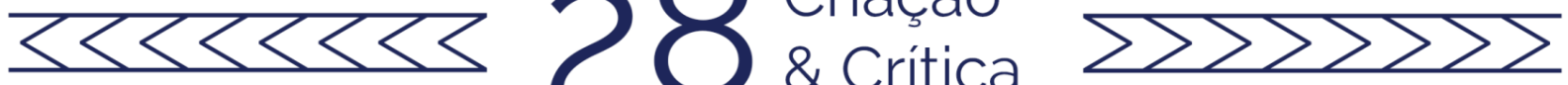

diante de outro aspecto imprescindível para o encontro entre o visitante estrangeiro e seu anfitrião: a comunicação em um mesmo idioma.

Nos jornais da época, no entanto, temos os relatos que um intercâmbio de ideias seria realmente difícil devido a total ignorância tanto da língua e da cultura francesa por parte dos brasileiros. Tal comentário, porém, nos parece surpreendente, pois nessa metade do século, o idioma era ainda bastante falado no Brasil e o gosto pela cultura francesa, ao menos entre nossa "elite cultural", era cultivado. Vejamos o exemplo na seguinte nota irônica, publicada no Suplemento Letras e Artes, que aponta ao mesmo tempo o problema da língua e de nossa exagerada hospitalidade:

Há também grande disputa em torno do posto de empresário de Camus, pois todos os grandes escritores de São Paulo querem ter a primazia de se mostrar me público dando tapinhas nas costas do autor de "L'Etat de Siège". Aliás já foi organizada uma compacta e heterogênea comissão de escritores para hospedar o colega francês enquanto estiver por aqui. $O$ mais interessante é que alguns desses senhores precisam urgentemente aprender o francês para conseguir dizer a Camus pelo menos frases convencionais...28

Mas nem sempre é necessário que visitante e anfitrião compartilhem de um mesmo idioma para que se compreendam mutuamente e, sob esse aspecto, podemos nos valer da tradução. Se, como nos lembra Steiner "compreender é traduzir" (1998), a acolhida de um visitante e a tradução de uma obra compartilham da mesma busca por uma recepção hospitaleira e por um encontro profícuo entre o escritor e os leitores.

Dessa forma, excluindo-se a "batalha" entre intelectuais que se acusam mutuamente com ironias por meio de artigos, os jornais, em especial o suplemento Letras e Artes, desempenham um importante papel para o encontro de Camus com seus leitores brasileiros. Em 24 de julho é publicada a tradução de uma conferência intitulada "O escritor e a nossa época" 29 , assinada por José Sanz, e que pode ser considerada o primeiro texto de Camus em português. Tal texto está em consonância com as intervenções que faz no Brasil e com as questões que ocupavam o espírito do escritor nessa época. No mesmo número, em tradução assinada por Agostinho Olavo, podemos encontrar alguns trechos da peça Calígula que seria encenada por uma companhia de teatro. Em 14 de agosto, em tradução de Maria da Saudade Cortesão, o suplemento publica o texto da conferência "Um moralista da revolta: Chamfort". ${ }^{30}$ Há ainda uma transcrição da conferência de Porto Alegre, "A Europa e o Morticínio”, publicada no

\footnotetext{
${ }^{28}$ Seção "S. Paulo nas Letras e nas Artes". Letras e Artes, Suplemento de A manhã, 2 ag. 1949.

${ }^{29} \mathrm{O}$ título original da conferência, proferida em Pleydel em novembro de 1948, era "Le témoin de la liberté" [A testemunha da liberdade]. Tal texto, portanto, não deve ser confundido com um texto posterior que receberá o título de "Écrivain et son temps". Cf. OC II, 2006, p. 488.

30 "Um moralista da revolta: Chamfort" em tradução de Maria da Saudade Cortesão, 14 de agosto de 1949, p. 13. "O escritor e a nossa época", 24 de julho de 1949, p.1 "Teatro de Camus" tradução de Agostinho Olavo, p. 4
} 

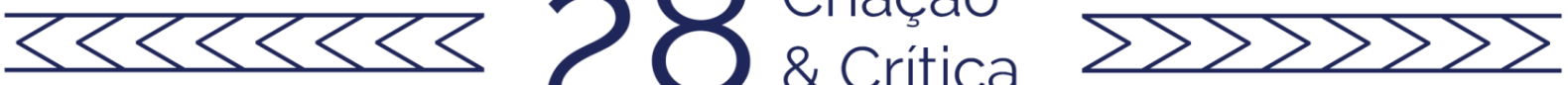

número 14 da Revista Província de São Pedro, cuja tradução e comentário são feitos por Jean Roche, adido cultural do consulado francês.

A vinda de Camus ao Brasil parece ter despertado o interesse dos leitores brasileiros, pois no ano seguinte (1950) A Peste é traduzida e publicada pela editora José Olympio. Feita por Graciliano Ramos, tal tradução, porém, é considerada controversa por conta de certas supressões e condensações que opera sobre a obra e pelo "uso de palavras e expressões próximas ao seu contexto, fazendo referência ao sertão e/ou aos hábitos do sertanejo." (BICA LHO, 2007, p. 59)

Em 1952, o Suplemento Letras e Artes publica a tradução de um trecho do Diário de Viagem enviado por Camus e ao qual intitula "Uma macumba no Brasil"31 (CAMUS, 2004, p.78), primeiro indício de que tal episódio seria reaproveitado em uma futura narrativa. A data do envio é importante, pois é nesse ano que Camus começa a datilografar a versão manuscrita de seus Cadernos (Carnets) que continham também os seus diários de viagem, e portanto, a revisitar as suas anotações.

Hoje, após 70 anos de sua visita, os principais livros de Camus estão disponíveis em português, o que mostra que o intercâmbio cultural deu frutos e que a recepção de sua obra seguiu o curso natural em uma época em que as ideias circulavam muito mais lentamente do que em nossos dias.

\subsection{As conferências: mensagem e missão}

Camus profere no Brasil quatro conferências: "O tempo dos assassinos"32, "Um moralista da revolta: Chamfort"33, "A Europa e o Crime"34 e "Romance e Revolta"35. O conteúdo de todas elas, apesar de provirem de textos já publicados ou ainda em gestação, se direciona ao tema da revolta que seria apresentado dois anos mais tarde em O Homem Revoltado e ao qual o público brasileiro pôde ter acesso em primeira mão. Podemos afirmar, assim, que o Brasil está de certa forma presente no ensaio de 1951, mas não nos é possível saber até que ponto a recepção das conferências e as discussões por elas suscitadas auxiliaram o escritor a perfazer aquela que pode ser considerada a sua obra maior.

\footnotetext{
31 Uma macumba no Brasil. Letras e Artes, Suplemento de A manhã, 23 mar. 1952, p. 6-7

32 Segundo Bartfeld (1995), trata-se da adaptação de um artigo de 1946, publicado pela revista Franchise e intitulado Nous autres meurtriers. No entanto, de acordo com as resenhas publicadas nos jornais da época, podemos notar também diversas semelhanças com o conteúdo de "Le témoin de la liberté", citado em nota anterior. O manuscrito da conferência está conservado no Fonds Albert Camus.

${ }^{33}$ Essa conferência retoma o conteúdo de um ensaio, publicado em 1944, intitulado "Introduction aux maximes de Chamfort".

${ }^{34}$ De acordo com os resumos publicados nos jornais de Porto Alegre notadamente, essa conferência guarda muitas semelhanças com "O tempo dos assassinos", mas sob outro título.

${ }^{35}$ Tratava-se de um texto até então inédito e que viria a se integrar, mais tarde, com ligeiras modificações, ao ensaio $O$ Homem Revoltado. Nós pudemos consultar o manuscrito desta conferência no Musée des Lettres et Manuscrits de Paris, em 2014 (hoje fechado), e confirmar que se tratava, como indica Quilliot no volume Essais da Bibliothèque de la Pléiade de um texto a parte no dossiê de gênese do ensaio, conservado pelo Fonds Albert Camus e denominado "Manuscrit Agnely".
} 

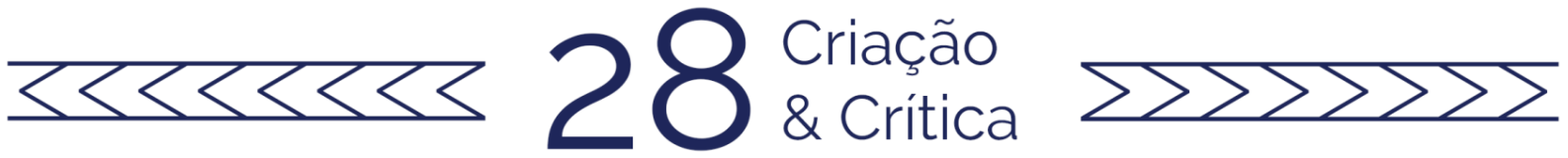

Em todas as conferências, o grande afluxo de público parece demonstrar o interesse pelas ideias que o escritor vem compartilhar em nosso solo. Na sua primeira conferência "O Tempo dos Assassinos" proferida no Rio de Janeiro, por exemplo, não houve espaço para todo o público em um auditório de 800 lugares e as pessoas tiveram que escolher entre sentar-se no chão ou ir embora, fato amplamente repercutido pelos jornais ${ }^{36}$.

Mas Camus interpreta tal afluxo como se sua mensagem não despertasse tanto interesse e o fato não passasse de um espetáculo. Sobre essa noite, o escritor anota que vê apenas "chapéus" e se pergunta porque chama tanto a atenção das mulheres. Um jornalista nos fornece talvez a explicação, ao compará-lo a uma estrela de Hollywood, um rival incontestável de Dana Andrews et Bob Taylor: "Tudo o que havia de mais chique no Rio de Janeiro se mobilizou para festejar o estranho moço de trinta e seis anos que era já um pensador, escritor, autor de teatro e ao mesmo tempo encantador." 37 Outro jornalista relata que ao iniciar sua conferência, Camus baixara a cabeça quase imperceptivelmente como se o grande espetáculo público fosse incompatível com seu espírito: "tantas toaletes maravilhosas, tanto esplendor feminino ante um homem que vinha falar de coisas sérias e graves"38.

Diante disso, devemos nos perguntar: os brasileiros compreenderam a mensagem de Camus em meio a tanto ativismo desnecessário?

Com respeito a forma como se transmitiu sua mensagem, escreve o adido cultural Jean Roche ${ }^{39}$, por sua sinceridade e clareza, Camus conseguiu tocar os outros homens, pois tinha o dom de saber falar aos outros. De fato, seu pensamento se baseia em um profundo humanismo que apela para um diálogo entre os homens, como se pode depreender ainda da conferência "O Tempo dos assassinos": "Não existe vida sem diálogo. $E$, na maior parte do mundo, o diálogo é substituído hoje em dia pela polêmica, a linguagem da eficácia. [...] Os homens vivem e só podem viver com base na ideia de que têm algo em comum onde sempre podem se encontrar." (CAMUS, 2008, p. 357)

Com o respeito ao conteúdo de sua mensagem, o já citado artigo de Leda Barreto parece ter captado bem que o objetivo da viagem de Camus representava bem mais do que um simples intercâmbio cultural ao apresentá-lo como um "missionário da paz". Denominação que, apesar de sua conotação religiosa, está em consonância com os escritos de Camus destes anos nos quais o mundo vivia ainda sob o impacto da Segunda Guerra Mundial ${ }^{40}$.

\footnotetext{
36 "A CONFERENCIA de Albert Camus no ministério da Educação". A manhã. 21 jul. 1949, p. 1

37 "CAMUS encontra o absurdo". Diário de Notícias. 7 ag. 1949.

38 "CAMUS no Ministério da Educação". Letras e Artes, Suplemento de A Manhã. Rio de Janeiro, 21 jul. 1949, p. 5.

${ }^{39}$ Correio do povo, 10 ago. 1949.

${ }^{40}$ Cf. por exemplo, a entrevista "Défense de l'homme" de 1949 e a conferência "L'Incroyant et les chrétiens" de 194 , no qual afirma a fraternidade de luta entre cristãos e incrédulos pela paz. (CAMUS, 2008a)
} 

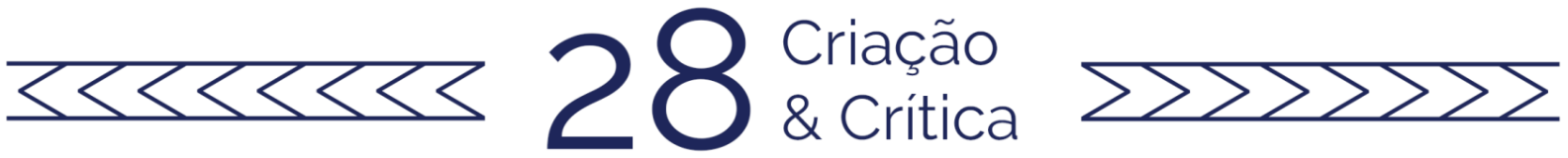

E um homem que tem algo a dizer e o seu talento e a sua arte ele os coloca a serviço da mensagem que tenta transmitir, entregando-se todo a sua idéia. Um missionário de sandálias e cordão na cintura, Camus é uma idéia tocando os homens e contagiando-os. E que diz ele? Camus fala de paz, aí está o segredo. Nossos ouvidos, cansados de guerra. Doídos de ameaças, pedem palavras de paz. [...] Alimentemos o seu archote: ouçamos a sua pregação, guardemos a suas palavras ${ }^{41}$.

Segundo a jornalista ainda, Camus não vem propagar em terras brasileiras a cultura francesa: por se tratar de um pensador universal, vem nos falar acerca dos problemas que dizem respeito a todos os homens. De fato, se considerarmos que a sua vinda se insere em um intercâmbio cultural, nada poderia ser mais desconcertante do que a maneira como introduz essa conferência ao apresentar a Europa como um continente doente: "Alguns de vocês demonstram a generosidade de se interessar pela Europa. [...] Este velho continente carrega muitas cicatrizes que the dão um aspecto sinistro. [...] Enfim, ele possui um passado, séculos de glória, o que nada significa, e de cultura, o que vale mais". (CAMUS, 2008, p.351) Mas se pergunta, em seguida, como essa terra do humanismo pôde produzir os campos de concentração.

Assim, podemos perceber que apesar de não se sentir à vontade em missão oficial como um representante dessa Europa, Camus considera que a sua viagem tem uma missão que não é diferente daquela de todos os seus escritos, pois não pode se separar da comunidade dos homens e de seus problemas. Como nos lembra no final dessa conferência, os artistas têm uma grande responsabilidade e um papel a desempenhar como testemunhas da vida e da liberdade.

No entanto, diversos relatos de tom acerbo zombam da "intelligentsia" brasileira e afirmam que, na verdade, nossos intelectuais não passavam de provincianos que, salvo raras exceções, ignoravam os grande autores e alienavam-se das grandes questões universais.

Entre essas exceções está Otto Maria Carpaux que parece esposar essa opinião quando escreve sobre a conferência "O moralista da revolta". Nas pausas desses trabalhos Camus fez conferências, uma que foi acontecimento mundano e outra sobre Chamfort, inspirando ao Rio de Janeiro a dúvida assustada: "Quem é Chamfort?" (1951, p. 15) De fato, Carpaux é um dos poucos a estabelecer um diálogo com a conferência proferida por Camus ao escrever o artigo intitulado "O Chamfort de Camus e dos outros"42.

Outros comentários chegam até mesmo a afirmar que parte desses supostos intelectuais e jornalistas não sabem quem é Albert Camus ou tampouco conhecem a sua obra. Tal crítica, porém, não é verdadeira. Nesse sentido, alguns artigos nos chamam particularmente a atenção, porque mostram não somente que seus autores conheciam as obras de Camus, mas que a compreenderam profundamente, oferecendo-

\footnotetext{
${ }^{41}$ BARRETO, Leda. "Um missionário da paz". A Manhã. Rio de Janeiro, 21 ag. 1949, p.3.

42 CARPEAUX, Otto Maria. "O Chamfort de Camus e dos outros". O jornal. Rio de Janeiro, 11 set. 1949, p. 1 e 4 .
} 

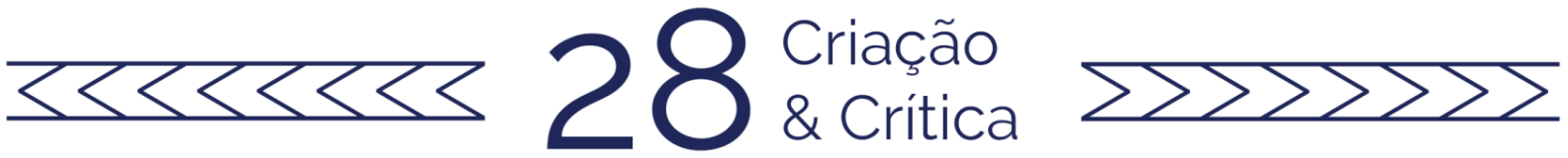

Ihe uma interpretação justa. Esses artigos são ainda mais surpreendentes pelo fato de que já apontam, em um momento em que 0 Homem Revoltado estava em plena gestação, para uma evolução de Camus do absurdo à revolta, interpretação que tais autores depreendem tanto da leitura de $A$ Peste quanto do conteúdo das conferências proferidas no Brasil. ${ }^{43}$

Camus, porém, ignorando, por questões óbvias, todos esses ecos e discussões que se originaram de suas falas em nosso país, permanecera com a impressão de que todo esse espetáculo, ao mesmo tempo intelectual e mundano, não passou de uma grande comédia, como anota em seu diário. No entanto, na mesma entrada, nuançando a sua opinião, ele revela que pode colher, apesar de tudo, alguns olhares verdadeiros durante as suas conferências. Apreciação que poderia ser estendida a toda a sua estadia em nossas terras.

Dessa forma, traçadas as grandes linhas desse intercâmbio cultural, voltemos nossos olhos para o contato pessoal travado por Camus com a nossa intelectualidade a fim de tentar discernir ali esses "olhares verdadeiros". Nos tópicos a seguir, apresentaremos a ideia de que uma das causas do desencontro entre Camus e os brasileiros se deveu à forma como o intercâmbio foi organizado, não permitindo um contato mais íntimo e demorado entre as partes.

\section{Encontros intimos}

\subsection{En petit comité}

Camus havia deixado a cargo do adido cultural a organização de sua viagem solicitando evitar um excesso de manifestações oficiais e justificara o pedido com a seguinte observação: "Posso estar enganado, mas tenho a impressão que aprendemos mais coisas em uma conversa a dois do que num banquete para 20 pessoas" (CAMUS, 2013). Como veremos a seguir, sua viagem não pode ser simplesmente taxada como um desencontro, pois o escritor apreciou a companhia daqueles com quem teve a oportunidade de estabelecer um diálogo mais íntimo.

Ele aprecia, por exemplo, o seu primeiro contato com uma jornalista que descreve como "míope e encantadora", à qual concede uma entrevista na Embaixada da França no Rio de Janeiro, onde decidira se hospedar. A simpatia parece ter sido recíproca, pois a matéria começa por uma elogiosa apresentação, primeiramente do escritor e, em seguida, do homem Camus:

\footnotetext{
${ }^{43}$ Cf. FIGUEIREDO, Guilherme. "Camus encontra o absurdo". Diário de Notícias. 07 ag. 1949. MENDES, Murilo. "Camus". Letras e Artes, Suplemento literário de A manhã. Rio de Janeiro, 7 ag. 1959 , p.5 e 13 JORDAO, Vera Pacheco "Sisypho e Diego". Diário de Notícias, Rio de Janeiro, 21 ago. 1949, Sessão 4, p.1 e 4. MACEDO, Sílvio de. "A consciência lúcida de Albert Camus". Diário de Pernambuco, Recife, 23 jul. 1949 p.2. Para uma análise pormenorizada da questão, conferir BARBIERI, 2017, p. 78-84.
} 

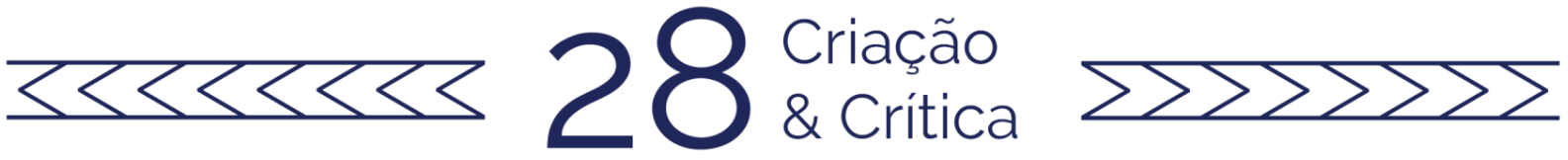

Pessoalmente Camus é um espírito transbordante em jovialidade, profundamente cavalheiro, cheio de humor, mas daquele humor muito francês que faz do parisiense o mais cordial e mais comunicativos dos homens. Tivemos essa impressão logo no primeiro contato, quando nos recebeu, ontem, na Embaixada da França, no Flamengo ${ }^{44}$.

Aliás, a foto que ilustra a matéria em que entrevistado e entrevistadora riem, deixa entrever o clima cordial e descontraído entre ambos ${ }^{45}$. Clima que parece marcar esses primeiros dias no Rio de Janeiro nos quais tem a oportunidade de desfrutar da companhia mais demorada de seus anfitriões. Ainda no dia de sua chegada, depois do almoço, participa de uma recepção na casa do adido cultural, onde estava presente, entre outras pessoas, a jornalista Luiza Barreto Leite, irmã de Barreto Leite, um dos que ciceroneava Camus no Rio. Em artigo intitulado não por acaso "Camus o ser humano", ao qual já citamos, a autora, além de demonstrar um profundo conhecimento da obra do escritor, evoca sobretudo o seu encontro com ele:

quando [...] entrei no repousante terraço do apartamento de Mme. Mineur, a admirável adida cultural que o novo espírito francês nos empresta atualmente, lembrei-me do episódio acima. Aquele homem que ali estava, com aspecto um pouco cansado, fisionomia marcada por uma vida interior, que é o reflexo de uma assimilação do mundo exterior, aquele homem de olhar agudo, claro e profundo que aperta a minha mão com a espontaneidade de um amigo, só poderia ser o dr. Rieux... ${ }^{46}$

Mas interessantemente, nesse encontro pessoal, autor e personagem se confundem no espírito da jornalista. Esse almoço havia terminado em um terraço diante da orla carioca, o que proporciona a Camus uma imensa sensação de bem-estar. Mas enquanto o escritor, em seu diário, se atém à descrição da natureza, Leite se atém à descrição das pessoas ${ }^{47}$. Camus aprecia ainda um almoço em que estão presentes ninguém menos que Manuel Bandeira e Dorival Caymi, que brinda os convivas com suas canções, e por quem o escritor fica completamente encantado.

\footnotetext{
44 "PRECISAMOS conquistar a paz e não esperar que a encontremos entre os presentes de ano novo". Gazeta de Notícias. 21 jul. 1949. p. 4

45 A foto que ilustra a matéria da época está disponível hoje no site do Memorial da Democracia:http://memorialdademocracia.com.br/card/albert-camus-no-brasil.

${ }^{46}$ LEITE, Luiza Barreto. "Albert Camus - o ser humano". Letras e Artes, Suplemento de A Manhã. 24 jul. 1949. p. 4

${ }^{47}$ Este encontro parece tê-la marcado de tal maneira que ainda a ele se refere em artigo de 7 de agosto, "Camus e os direitos autorais": "Lembrei-me então da conversa que havíamos tido na mesma tarde de sua chegada. Estávamos cinco pessoas apenas em face do mar e da quietude que cerca a enseada de Botafogo: Mme Mineur - a anfitriã - traço de união entre o nosso amor pela França e a ressureição de seu espírito, Aníbal Machado, meu irmão, Barreto Leite Filho, eu e Albert Camus, naturalmente, desde a paisagem, até o espírito universal dos dois franceses - astronoma [sic] que nos recebia e o escritor que era recebido por nós. No meio das conversas gerais, falou-se de teatro e de sua importância como elementos comunicação entre os povos." Luiza Barreto Leite foi atriz, crítica e diretora de teatro. Letras e Artes, Suplemento de A Manhã, 7 ago. 1949, p.
} 

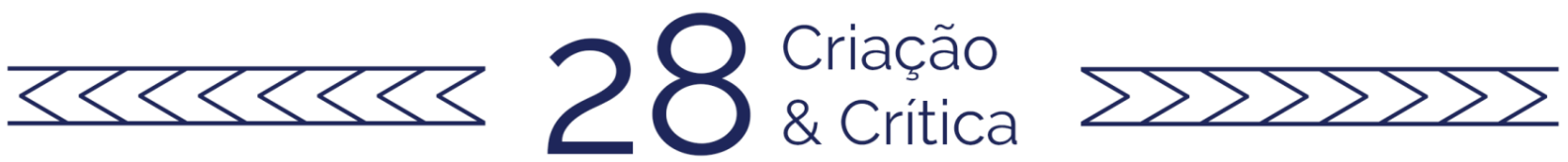

Como podemos ler na entrada do dia 16 de julho, Camus aprecia em nossas terras a companhia de franceses e daqueles cuja cultura francesa é patente, como anota acerca de um almoço, no qual fora acompanhado por Barreto Leite, na casa de certa romancista e tradutora não nomeada em seu diário.

Almoço com Barleto na casa de uma romancista e tradutora brasileira. Casa encantadora, agarrada a uma colina. Há muita gente, naturalmente; entre as pessoas, um romancista que teria escrito os Buddenbrook brasileiros, mas que representa um estranho caso de cultura incompleta. Se o que B. me diz é verdade, pode-se ouvi-lo dizer "autores ingleses como Shakespeare, Byron ou David Copperfield". No entanto, leu muito. Como a mim pouco importa que ele confunda David com Charles, acho antes que se trata de uma boa cabeça. No almoço, um couscous brasileiro, mas é um bolo de peixe. Os convivas se espantam quando peço para assistir a uma partida de futebol e literalmente deliram ao descobrir que tive uma longa carreira de jogador de futebol. Encontrei, sem querer, sua paixão principal. Mas a dona da casa traduz Proust, e a cultura francesa de todos é realmente profunda. Em seguida, proponho a B. que passeemos pela cidade, ele e eu. (CAMUS, 2004, p. 76)

Levando em conta essa última pista é provável que Camus tenha almoçado na casa de Lúcia Miguel Pereira ${ }^{48}$. O apartamento de Lúcia e de Tarquínio de Souza, seu esposo, era um dos pontos de encontro preferidos de todos os intelectuais importantes da época. Lúcia conhecia muito bem a obra de Camus, sobre a qual, aliás, havia publicado alguns artigos ${ }^{49}$. Entretanto, o encontro de ambos, se ocorreu, foi muito rápido para que dele nascesse algum laço para além da viagem: tão rápido que não deixa traços nem para Camus nem para Lúcia, ${ }^{50}$ que era uma das poucas a escrever sobre o escritor muito antes de sua vinda ao país. A importância do escritor para a "dama da crítica", como costuma ser chamada, foi tão grande que a coletânea de seus artigos escritos entre 1947 e 1955 recebeu o título de "O século de Camus" (2015).

Entre as diversas causas aqui já elencadas para essa impressão geral de desencontro entre Camus e o Brasil se deve sem dúvida a esse contato breve, permeado de tantas atividades, o que não permitiu o estabelecimento de diálogos mais frutuosos.

\subsection{Encontros intelectuais, simpatia e admiração}

Ao longo de sua estadia, apesar de todas as atividades impostas pelo intercâmbio oficial, Camus experimentou momentos agradáveis na companhia de alguns brasileiros com quem pode conviver mais longamente. Foi o caso, por exemplo, do jornalista Barreto

\footnotetext{
${ }^{48}$ Lúcia traduziu o último volume de Em busca do tempo perdido, a saber, O Tempo Redescoberto.

49 PEREIRA, Lúcia Miguel. "Uma testemunha". Correio da Manhã, 16 maio 1948, p.1.

${ }^{50}$ A biblioteca de Lúcia e Tarquínio contém dois exemplares de livros de Camus, um Le Mythe de Sisyphe e outro de L'homme révolté, mas sem dedicatórias.
} 

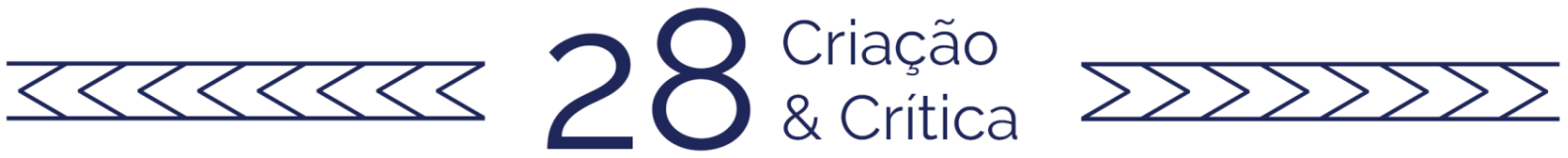

Leite (identificado como Barleto ou apenas B. no Diário de viagem), com quem o escritor simpatiza, e que o acompanha durante sua estadia no Rio tanto nas atividades oficiais quanto nos passeios ${ }^{51}$. É ao lado do jornalista que o escritor passeará pelo Rio de Janeiro e visitará Santa Teresa, um bairro operário e uma favela não nomeados. Circulam pela cidade de bonde, de trem e pegam até mesmo uma lotação! Em algumas dessas aventuras, como a visita a um terreiro de macumba (Barreto chega a levar um tombo descendo o morro), também são acompanhados por Aníbal Machado, descrito por Camus como "uma espécie de tabelião magro, culto e espirituoso" e pai de seis filhas "todas bonitas" (e entre elas, uma que se tornou bastante conhecida, Maria Clara Machado).

Em Salvador, aprecia a companhia de Eduardo Catalão "um brasileiro encantador" com quem vai a um candomblé. As cenas presenciadas no ritual da macumba e do candomblé se misturarão na escrita da novela "A Pedra que cresce", que tira o essencial de sua trama, no entanto, da visita feita à cidade de lguape, no interior de São Paulo, em que fora acompanhado pelo poeta Oswald de Andrade. Oswald foi, sem dúvida, um dos que mais passaram tempo com Camus, mas é descrito brevemente no diário como um "personagem notável", descrição à qual o escritor pretendia retornar, uma vez que a anotara entre parênteses que deveria "desenvolvê-la". (CAMUS, 2004, p.97)

Segundo Mario Pedrosa (1960), a visita a Iguape foi um dos momentos mais felizes e evocativos da passagem do escritor pelo Brasil e seu objetivo era mostrar ao escritor a festa do Divino, uma manifestação religiosa popular. A viagem recebe especial atenção no diário de Camus, que anota detalhadamente as "coisas vistas" durante a curiosa estadia na qual se hospedam em um hospital desativado que nem mesmo dispunha de água corrente. Oswald, por sua vez, também guarda com cuidado as lembranças, em forma de registros fotográficos, desses dias vividos ao lado do francês. Nas fotos, podemos ver a travessia do rio Ribeira em uma balsa, Camus cercado por seus companheiros de viagem (Oswald, seu filho Rudá, adido cultural Paul Sylvestre e o motorista apelidado por Camus de Auguste Comte), em seguida, diante da basílica do Bom Jesus de Iguape e, finalmente, deitado na cama improvisada no hospital enquanto escrevia ${ }^{52}$.

De tudo o que conversam, o que mais parece chamar a atenção do francês são as ideias de Oswald sobre a cultura e povo brasileiro. Em 3 de agosto, ele anota:

"Em seguida, Andrade me expõe sua teoria: a antropofagia como visão do mundo. Diante do fracasso de Descartes e da ciência, retorno à fecundação primitiva: o matriarcado e a antropofagia. O primeiro bispo que desembarca na Bahia tendo sido comido por lá, Andrade datava sua

\footnotetext{
51 O jornalista lhe dedica o artigo "Dois franceses". O jornal, 25 de junho de 1949, p.2.

52 Fundo Oswald de Andrade, CEDAE, UNICAMP. Essas fotos foram transmitidas por mim a filha de Camus, e publicadas em em seu último livro Albert Camus, le monde en partage, Paris : Gallimard, 2013. Em comemoração ao 70 anos da passagem do escritor pelo país, estas fotos foram publicadas na obra Camus, o viajante em 2017 pela Editora Record. As fotos do hospital podem ser vistas no artigo GESKE, Samara "Camus, un étranger au Brésil?" Albert Camus, Carte Blanche Les Rencontres Méditerranéennes Albert Camus, Editions Barthélemy: Avignon, 2014. p. 79-101
} 

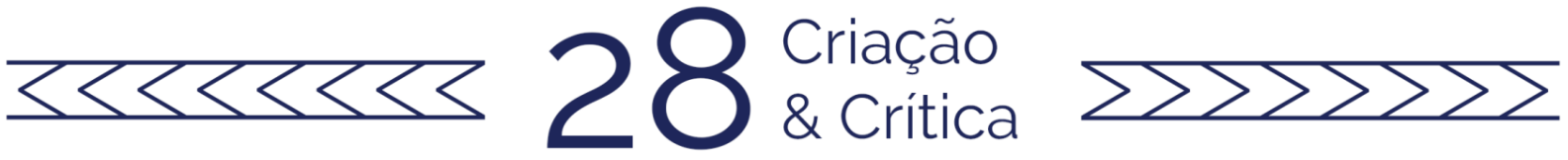

revista como do ano 317 da deglutição do bispo Sardinha (pois o bispo chamava-se Sardinha)." (CAMUS, 2004, p. 99)

Os livros com dedicatórias que Camus envia a Oswald testemunham que a relação entre os dois se estendeu para além da viagem e, em quase todas, há uma menção à antropofagia ${ }^{53}$. A admiração de Oswald pelo poeta René Char aumenta ainda mais a simpatia de Camus por ele. Em carta escrita a Char ainda no Brasil (CAMUS; CHAR, 2010, p.43-45), ele cita alguns de seus admiradores, além de Oswald, Paul Sylvestre e Murilo Mendes, e envia o endereço dos três para que o poeta francês lhes envie exemplares dedicados.

Conhecedor e admirador de René Char também era Murilo Mendes, que considerava o poeta francês mais importante depois de Rimbaud. Camus não somente anota o comentário de Mendes em seu diário, como acrescenta: "Fico contente com isso."

Mendes é incluído na pequena lista dos "dois ou três" que se destacaram para Camus no Brasil. A simpatia pelo poeta pode ser entrevista nas descrições, ainda que lacônicas, como esta: "espírito fino e resistente". Mendes recebe ainda o epíteto de "poeta e doente" em referência à tuberculose - doença da qual Camus também padecera, um ponto, sem dúvida triste, de afinidade entre ambos. Murilo Mendes, por sua vez, também manifesta sua simpatia pelo escritor. Segundo o poeta não haveria diferença entre o homem Camus e seu papel como pensador: "franco, leal, situado numa linha de generosidade que vai se tornando rara, sensível à amizade."54

É certo também que o domínio do francês e a profunda cultura de Mendes tenham colaborado para o estabelecimento de um contato mais profundo (ROSAL; LUCCHESI, 2016). Camus passou bastante tempo na "gentil companhia" de Mendes e sua esposa, Maria da Saudade Cortesão, e a relação entre ambos foi a que parece ter dado mais frutos. A simpatia e afinidade parecem ser recíproca e se estabelecem sob bases que são preciosas para o poeta que acabara de se converter ao catolicismo e que encontra, no escritor francês e descrente, um campo comum de interesse: o papel do artista como testemunha, noção fundamental para $\operatorname{ambos}^{55}$. No mesmo artigo em que saúda o escritor escreve esta apreciação, fruto, sem dúvida, das longas conversas que travaram:

\footnotetext{
${ }^{53} \mathrm{Em}$ um exemplar de Le Malentendu/Caligula : «à Oswald de Andrade qui unit les raffinements des grands européens au cœur vrai de ses chers primitifs/ son confrère et son ami/Albert Camus» ; e Les Justes: «à Oswald de Andrade, cette histoire d'anthropophagie/ en souvenir fidèle des beaux jours d'Iguape/et avec l'amitié des cannibales/Albert Camus. "Collection Oswald de Andrade, CEDAE/UNICAMP Para ver as imagens dos livros com dedicatórias, conferir GESKE, Samara "Camus, un étranger au Brésil?" Albert Camus, Carte Blanche Les Rencontres Méditerranéennes Albert Camus, Editions Barthélemy: Avignon, 2014. p. $79-101$

${ }^{54}$ MENDES, Murilo. "Camus". Letras e Artes, Suplemento de A manhã. Rio de Janeiro, 6 ag. 1949, p.5

${ }^{55}$ Mendes, aliás, começa seu artigo sobre Camus evocando tal noção: "O valor principal da pessoa e da obra de Albert Camus reside, a meu ver, no fato de ele ser uma testemunha extremamente sensível do drama da nossa época, mas uma testemunha que pensa e age por conta própria, não se resignando em ser o agente de nenhum partido nem de nenhuma seita." MENDES, Murilo. "Camus". Letras e Artes, Rio de Janeiro, 7 ag. 1949, p.5
} 

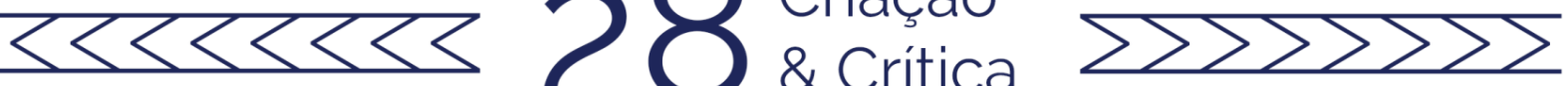

"O autor de 'Le Mythe de Sisyphe' tinha inúmeros motivos para desesperar; e, embora haja penetrado a fundo a filosofia do desespero, nega-se a descrer no homem e de sua possibilidades de liberação [...] Hum homem que não possui a fé religiosa, que compreende como poucos o estado de absurdo, que também não acredita nos ídolos da ciência e do progresso, que se ri dos paraísos oferecidos pela propaganda dos partidos políticos, esse amor à vida, essa obstinação em perseguir a ideia da felicidade assume aspectos comoventes." (MENDES, 1949, p.5)

Como de fato, testemunha o diário, Camus teve oportunidade de travar conversas mais longas com Mendes e, depois de sua partida, passaram a se corresponder. Parte dessa correspondência, a saber, algumas das cartas escritas pelo poeta, foram publicadas (GUIMARAES, 2012). Uma das missivas, por exemplo, menciona o encontro que ambos tiveram em 1954, em Paris, por ocasião de uma conferência que o poeta proferiu na Sorbonne, quanto estava em missão cultural pela Europa.

A visita de Camus dá ensejo a diversas publicações de Mendes e Maria da Saudade no suplemento Letras e Artes e, após a sua morte, o poeta lhe dedica um dos poemas de Retratos Relâmpagos que começa pela menção à amizade entre ambos ${ }^{56}$.

Camus, por sua vez, envia livros com dedicatórias para Mendes ${ }^{57}$, sem esquecer de mencionar, é claro, Maria da Saudade, cuja cultura e gentileza haviam-no marcado durante sua estadia. Foi justamente essa gentileza que ensejou o encontro entre Camus e Manuel Bandeira, que havia perdido a oportunidade de assistir à conferência do escritor devido à lotação do auditório. Convidado para um almoço em homenagem a Camus, no qual estavam presentes muitas pessoas, talvez nunca tivessem se falado se Maria da Saudade não tivesse cedido seu lugar ao nosso "poeta nacional", epíteto recebido por Bandeira no Diário. Como rememora o poeta em um texto, aliás, chamado "Recordação de Camus", a oportunidade de falar tête-à-tête com o francês lhe pareceu, de início, um pouco decepcionante. Sem saber direito o que falar, Bandeira lançara simplesmente: "Esses almoços em restaurante me cansam muito." Ele não poderia ter encontrado as palavras mais corretas para começar a conversação:

"A simpatia de Camus foi total. - 'A mim também', respondeu. E eu prossegui: - 'O senhor deve estar exausto de tanta conferência, tanta homenagem'. E ele: - 'Estou doente. Eu resisti à guerra, resisti à Resistência, não resisti à América do Sul!' Por aí fomos num papo sem nenhuma formalidade, falamos de nossa doença (porque Camus também

\footnotetext{
56 "Conheci-o de perto, usava o cilício da lucidez, as alpercatas da crítica. De rigor ético. De exigência estética. Era jovem, mediterrâneo. Recebendo a luz na mão, levantava-a, copo. Também colhia o movimento, flecha. Queria visar justo, experimentar sua resistência. Exercer a pietas. Romper o pão com o adversário. O movimento apanhou-o na sua roda de fogo. Ele, que toda a vida meditava o absurdo, absorveu-o." (MENDES, 1994, p. 1239)

${ }^{57}$ Dedicatória em um exemplar de Actuelles II: "à Madame Mendes et mon cher Murilo Mendes avec la fidèle et amicale pensée de leur Albert Camus. Je quitte Paris du 23 décembre au 30 janvier. Prévenez-moi d'un de vos passages avant et après cette date. M., votre conférence était très belle, et émouvante. Votre A. C." cf. ARAUJO, 2000.
} 

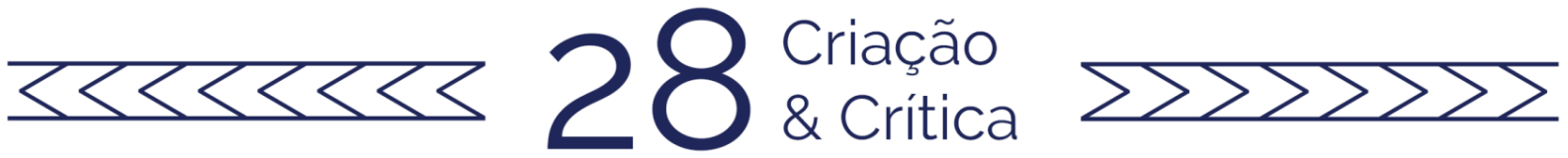

foi dos marcados pela tuberculose na mocidade), falamos de muitas outras coisas e ele acabou dando-me o seu telefone privado em Paris para que eu o procurasse quando fosse à França. Durante todo o tempo que o ouvi, senti-me à vontade e encantado. Surpreso. Não havia naquele homem vestígio dessa personagem odiosa que é a celebridade itinerante. Não parecia um homem de letras. Era um homem da rua, simples homem, dando a outro homem um pouco de sua substância espiritual, simplesmente humana. Senti vontade de ser seu amigo." (1997, p. 283)

Como Bandeira percebe, Camus não havia "vestido" a máscara da celebridade ou do homem de letras em viagem. As pessoas que mais lhe agradam são as que lhe falam sinceramente, sem pompas. O que alguns anfitriões não perceberam, e o que não cansa de reiterar, é que aprecia o diálogo, o simples contato entre os homens. Camus e Bandeira encontram em sua doença, a tuberculose, uma afinidade e um assunto para a conversa. Mas podemos também nos entregar ao exercício do diálogo imaginário entre ambos por meio de suas obras. Deveras, os poemas de Bandeira lidos à luz dos escritos de Camus permitem um "encontro" ainda mais profundo entre ambos, por meio de temas comuns que perpassam pelas suas obras, como a nostalgia da infância, a doença, a morte, e a visão ao mesmo tempo desencantada e exaltante diante da vida.

Entre esses contatos que se estenderam para além da viagem, também podemos incluir o jornalista Mario Pedrosa que, na verdade, já havia entrevistado Camus no ano anterior, em Paris ${ }^{58}$. Pedrosa havia acompanhado Camus em diversas atividades e pôde com ele conversar mais longamente, como se recorda em 1960, "sobre os perigos da guerra e do totalitarismo, a solidariedade internacional etc.." $\mathrm{E}$ relembra um dos propósitos principais de sua viagem: "Costumava dizer: viera ao Brasil fazer algumas amizades" ${ }^{59}$. Segundo Mauritônio Meira, também em um necrológio ${ }^{60}$, Camus havia deixado no Brasil "vários amigos com os quais mantinha correspondência e para os quais mandava seus livros sempre com dedicatórias cordiais". De fato, nas Edições das Obras Completas do autor, encontramos uma carta cujo destinatário desconhecido é, sem dúvida, um jornalista brasileiro, pois termina nos seguintes termos: "Transmita minha afetuosa lembrança aos meus amigos do Brasil”. (CAMUS, 2008a, p. 1092)

\subsection{O encontro ficcional}

Na primeira entrevista concedida no Brasil, Camus havia manifestado o desejo de "compreender a gente brasileira mais na intimidade." ${ }^{11}$ Mas ao chegar ao final de sua estadia, em Porto Alegre, lamentara que o ritmo das conferências o tivesse impedido de

\footnotetext{
${ }^{58}$ PEDROSA, Mário. "Ouvindo Albert Camus". Correio da Manhã. Rio de Janeiro, 14 ag. 1948, p.1.

59 PEDROSA, Mario. "Camus e a nossa realidade". Jornal do Brasil. 08 jan. 1960, artigo no qual relata que continuou a se corresponder com o escritor. Nas cartas trocadas com Murilo Mendes, o poeta conta que foi Pedrosa quem Ihe passou telefone de Camus.

60 "A MORTE de Camus cobriu de luto a literatura mundial. Jornal do Brasil. 5 jan. 1960

61 "O PENSAMENTO de Albert Camus". Correio da Manhã. 20 jul.1949, p. 1.
} 

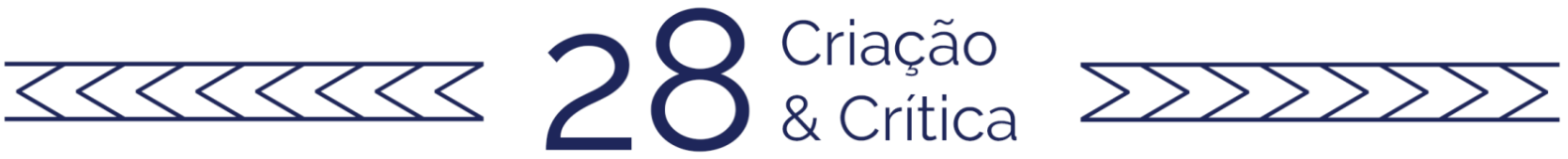

entrar em contato mais íntimo com o povo brasileiro. Prometera, entretanto, que na primeira oportunidade regressaria ao Brasil, para, então, desobrigado de pronunciar conferências, misturar-se com o povo brasileiro ${ }^{62}$. Ao regressar à França, porém, declarou que não pretendia retornar ao Brasil em missão oficial ${ }^{63}$, pois afinal de contas retornara a Paris "sem ter visto o país e sem ter entrado em contato com seu povo". 64 Mas como ele mesmo reconhece no diário, seriam necessários muitos anos para aqui se integrar e pergunta a si mesmo: "Será que sinto vontade de passar alguns anos no Brasil?" A resposta é cabal: "Não". (CAMUS, 2014, p. 106)

No entanto, dois meses após seu retorno à França, andando pelas ruas de Paris, uma lembrança olfativa Ihe assalta: o cheiro aromático de café e de especiarias e também dos fogos do interior do Brasil. (CAMUS, 2008, p. 1059). Curiosamente, Claude LeviStrauss que percorreu nosso país de norte a sul bem mais calmamente que Camus, da mesma forma, pensa no Brasil como num perfume queimado. $\mathrm{E}$ ao revisitar as imagens que guardara de suas excursões por nossas terras, o antropólogo nos oferece uma chave de leitura para interpretar o uso que Camus faz de suas anotações para a gênese de uma narrativa. Levi-Strauss considera que a verdade de uma situação não se encontra na sua observação momentânea: é preciso que o tempo sedimente as impressões, a lembrança de uma cena fugidia, certa reflexão anotada rapidamente. Um dia, como em uma escavação arqueológica, tudo isso é reencontrado, e aquilo que outrora parecera sem sentido ou estéril é, enfim, compreendido e interpretado (1996, p. 45-46). O processo de criação de uma obra literária pode ser pensando nos mesmos termos: um dia, ao ser interrogado por um jornalista sobre seu método de trabalho, Camus respondera que tudo começava de forma muita vaga, com notas lançadas em seus cadernos ou em pedaços de papel aleatórios durante anos. Um dia vinha a ideia da concepção de uma obra e essas partículas esparsas se coagulavam, enfim, em um texto (CAMUS, 2006, p.35).

No início de 1952, quase três anos após sua viagem, surge a ideia para uma novela sobre o Brasil na forma uma pequena nota que contém os elementos para um enredo: "Iguape. Um homem à frente da balsa. A cidade, a procissão. O homem, a pedra tombam. O visitante carrega a pedra mas ultrapassa a igreja e anda em direção ao rio. Ele carrega uma longa barca com a pedra e sobe o rio em direção à floresta virgem onde desaparece" (CAMUS, 2008, p. 1129). É a partir desse plano que vão se coagular as diversas notas lançadas no diário. Como já indicamos, esse é o ano em que o escritor revisita suas notas para um versão datilografada do diário e que começam a surgir

\footnotetext{
62 "EXPRESSIVA recepção teve, em Porto Alegre, o famoso escritor francês". Diário de Notícias. 10 ag. 1949, p. 2.

${ }^{63}$ Como sabemos, no dia 23 de julho, Camus profere uma conferência na Universidade da Bahia. Anos mais tarde, o reitor da universidade envia por intermédio do pintor Cicero Dias um convite para que o escritor participe do 10 Colóquio de Crítica e História Literária que ocorreria em agosto de 1960. Em carta o reitor, Dias lamenta a morte de Camus e informa que este havia acolhido com grande interesse o convite, mas que temia ficar doente durante a viagem, cansativa para um homem da sua constituição física. In: Jornal do Brasil, 19 de janeiro de 1960.

64 "O ANO literário de 1949". Correio da Manhã. 25 dez. 1959, 4 seção.
} 

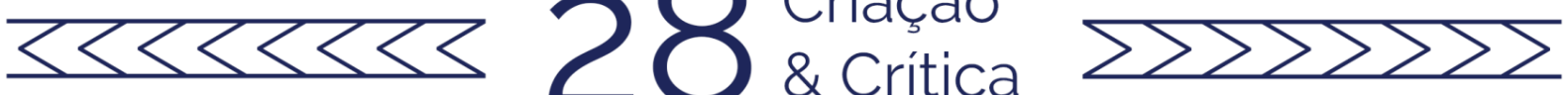

diversas menções a "Iguape" ou a uma "novela Brasil" (CAMUS, 2008, p. 1139-1140). Em 1955, três anos mais tarde "A Pedra que cresce" é terminada (CAMUS, 2008, p.1377).

O plano de 1952 se baseia precisamente na história contada por um brasileiro com o qual o escritor se encontrara durante a Festa do divino em Iguape, que Camus registrara em seu diário da seguinte forma: "[um peregrino] com um ar de assírio, ornado de uma bela barba negra, conta-nos que foi salvo de um naufrágio pelo Bom Jesus, após uma noite e um dia passados nas ondas furiosas, e que fez a promessa de carregar na cabeça uma pedra de sessenta quilos durante a procissão." (CAMUS, 2004, p. 106) 0 homem, apesar de cansado, consegue pagar a sua promessa sem dificuldades.

Na novela "A Pedra que cresce", é o engenheiro francês d'Arrast, em missão no Brasil, que vai a lguape para se ocupar da construção de um dique. Lá vive as mesmas peripécias que Camus em sua estadia na cidade e se torna amigo de um cozinheiro de embarcação, que por ter sido salvo de um naufrágio, faz a promessa de carregar uma pedra durante a procissão da festa do Bom Jesus. Na véspera, porém, vai a uma macumba - cuja descrição também se alimenta daquela presenciada pelo escritor no Rio de Janeiro -, bebe e dança demais. No dia seguinte, sem forças para sustentar a pedra e cumprir sua promessa, acaba desfalecendo no meio do caminho. D'Arrast, diante disso, inclina-se sobre ele, limpa seu ombro manchado de sangue e poeira "enquanto 0 homenzinho, com a face colada à terra, ofegava. Ele não ouvia nada, não se mexia mais. [...] D'Arrast o tomou nos braços e o ergueu quase tão facilmente como se se tratasse de uma criança. Mantinha-o de pé, encostado nele." (CAMUS, 1997, p. 171).

Mas o homem não consegue mais prosseguir. O engenheiro toma então a pedra para si e entre gritos que lhe indicavam o caminho da Igreja e se dirige ao casebre do pagador de promessas: "Apressou o passo, chegou afinal à pequena praça onde se erguia o barraco do cozinheiro, correu até lá, abriu a porta com um pontapé, e, com um único movimento, atirou a pedra no centro do cômodo, sobre a fogueira ainda em brasa." (CAMUS, 1997, p.172) Como se nota, o desfecho da narrativa muda em relação ao planejado inicialmente, um final que era deveras enigmático. Mas outra razão parece ter levado a essa mudança. No interior da reunião de novelas intitulada O Exílio e o Reino, "A Pedra que cresce" ocuparia o último lugar. A narrativa anterior, "Jonas, ou o artista no trabalho" terminava por uma aporia: uma tela na qual o pintor havia esboçado apenas uma palavra que não se podia identificar se se tratava de "solitário" ou "solidário". Essas duas palavras, porém, são muito importantes na economia da obra camusiana, pois a passagem do absurdo à revolta se opera justamente por uma recusa à solidão em prol da solidariedade ${ }^{65}$.

\footnotetext{
${ }^{65} \mathrm{Em}$ O Homem Revoltado, lemos: "Na experiência do absurdo, o sofrimento é individual. A partir do movimento de revolta, ele ganha a consciência de ser coletivo, é a aventura de todos. O primeiro avanço da mente que se sente estranha é, portanto, reconhecer que ela compartilha esse sentimento com todos os homens, e que a realidade humana, em sua totalidade, sofre com esse distanciamento em relação a si mesma e ao mundo. O mal que apenas um homem sentia torna-se peste coletiva. Na nossa prova diária, a revolta desempenha o mesmo papel que o cogito na ordem do pensamento: ela é a primeira evidência. Mas
} 

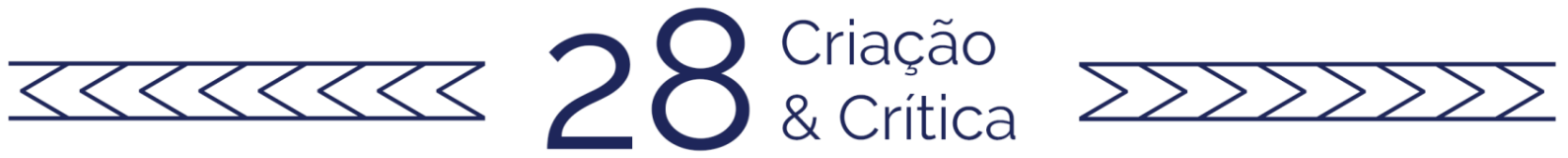

Dessa maneira, como não interpretar essa mudança no final da narrativa à luz da passagem do "homem absurdo" ao "homem revoltado", ensaio que estava em plena gestação quando da viagem ao Brasil e no qual a superação da absurdidade da existência individual se dá por meio da relação solidária entre os homens? E sem dúvida que a presença da pedra dá ensejo e confirma essa mudança, pois como não pensar no trabalho absurdo de Sísifo que carregava uma pedra em direção ao cimo de uma montanha de onde ela sempre rolava para que tudo recomeçasse. Porém, agora, Sísifo não está mais sozinho, uma mão solidária não somente o levanta, mas ajuda-o a carregar a pesada pedra.

Ao longo da história o engenheiro francês D'Arrast - que como todos os personagens das novelas de $O$ Exílio e o Reino, funciona como um alter-ego do escritor experimenta a solidão sob a forma de um exílio que é mais do que apenas geográfico, ele se sente deslocado entre os brasileiros. Por exemplo, a razão que dá para ter deixado o terreiro de macumba na qual acompanhara o cozinheiro é que não havia encontrado ali o seu lugar (sentimento que fora vivenciado pelo próprio Camus durante a sua ida a um terreiro). D'Arrast, porém, esperava por algo, como se o trabalho que viera realizar no Brasil não passasse de um pretexto para "a oportunidade de uma surpresa, ou de um encontro que ele nem mesmo imaginava, mas que o teria esperado, pacientemente, no fim do mundo" (CAMUS, 1997, p. 150). Finalmente, se D'Arrast não encontra o seu "reino", ao menos não é mais um exilado quando se integra ao povo brasileiro na cena final em que, já dentro do casebre, indicam-lhe um lugar vazio e alguém o convida: "Sente-se conosco" (CAMUS, 1997, p.174). A novela termina com essas palavras e o casebre se torna o ponto de encontro, não entre dois países e duas culturas, como pressupõe o intercâmbio cultural, mas entre simples homens.

\section{Conclusão}

Nossa leitura da viagem de Camus ao Brasil apresentou concomitantemente a ideia de um desencontro e a de um encontro, ambos válidos e apoiados por nossa pesquisa e argumentação. Como na tela do pintor de "Jonas ou o artista no trabalho", nosso artigo poderia assim se resumir, para que fosse mantida tal tensão de perspectivas: (des)encontros.

Excetuando-se as causas "oficiais" que levaram a um desencontro entre Camus e o Brasil, elucidadas em nossa primeira parte sobre o intercâmbio oficial, não citamos, no entanto, uma possível falta do próprio escritor. Nesse sentido, a sua visita deixa, para algumas pessoas com quem ele travara contato o sentimento de pesar, ainda mais marcado por seu falecimento em 1960. No necrológio escrito pelo jornalista Mario Pedrosa, lemos: "Temo que, lúcido e probo, Camus não nos olhou com muita 

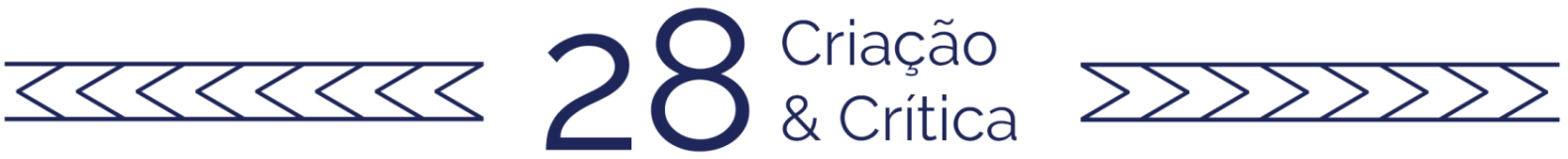

condescendência. A sua passagem pelo Brasil foi, como diz em carta que me escreveu, uma corrida infernale."66

Cabe lembrar que nos primeiros escritos de Camus (os ensaios de Núpcias e $A$ morte feliz), a viagem a um país estrangeiro está ligada a uma experiência angustiante que revela aos personagens a estranheza dos homens e do mundo. Mas logo nos vem à mente a abertura ao "estranho/estrangeiro" que significou a escrita de "A Pedra que cresce", única narrativa camusiana que não tem como plano de fundo a Europa ou seu país natal, a Argélia. Há que se salientar também que na novela não encontramos muitos traços de idealização e notas de exotismo, abundantes, no entanto, em escritos de europeus sobre o Brasil (cf. TETTAMANZI, 2004, p. 273).

Alguns, porém, podem ver na novela uma espécie de antropofagia oswaldiana que busca deglutir simbolicamente a cultura do outro para criar uma cultura local original, visto que Camus vai integrar as experiências vividas no Brasil no interior de seu próprio pensamento.

Mas como procuramos mostrar, a novela seria uma tentativa de criar um espaço de encontro possível, construído por meio da busca de um diálogo entre simples homens com aquilo que eles têm em comum, com o que os une acima dos povos e das raças: a sua própria humanidade. Tal assimilação, portanto, indo do particular ao universal, buscaria percorrer o caminho inverso daquele proposto pela antropofagia cultural, uma vez que as notas de seu Diário de viagem são reorganizadas em uma história cujo tema é a fraternidade entre os homens.

Ainda que, pelos motivos elencados ao longo deste artigo, a viagem de Camus deva ser vista simultaneamente como um encontro/desencontro, consideramos que a "correção" da realidade por meio da narrativa ${ }^{67}$ - conscientes de todas as limitações que esta empreitada implica - possa ser encarada na perspectiva positiva de um encontro.

Se, como afirma Paul Ricœur (2006), as intrigas ficcionais que criamos são um meio privilegiado de re-configurar nossa experiência, de re-descrever e re-significar o mundo, os desencontros e os encontros fugazes vividos durante a viagem são coroados por um grande, profundo e verdadeiro encontro por meio da ficção, que é uma das formas de compreender e de nos identificar com os outros por meio da imaginação.

$E$, nesse ponto, podemos observar certa semelhança entre a acolhida recebida pelo visitante e a recepção de sua obra, uma vez que a hospitalidade literária não nos

\footnotetext{
66 PEDROSA, Mario. "Camus e a nossa realidade". Jornal do Brasil. 08 jan. 1960. Tal carta a qual se refere Pedrosa, pode ser aquela a nos referimos no final do tópico 3.2, publicada nas Obras Completas e acompanhada por uma entrevista que terminava com a seguinte resposta: "Minha viagem à América do Sul? Uma corrida infernal" (CAMUS, 2008a, p. 1095)

${ }^{67} \mathrm{Em} \mathrm{O}$ Homem Revoltado, particularmente no tópico sobre as relações entre a arte e a revolta, Camus nos apresenta ao conceito de "criação corrigida". Um dos aspectos do qual se reveste a revolta, a saber, a revolta metafísica se dirige ao aspecto inacabado e frustrante da existência. O romance, por exemplo, busca uma unidade que não existe na vida e que só pode ser alcançada por uma transformação que o escritor impõe ao real. Esta correção se opera por meio da linguagem e por uma redistribuição dos elementos provenientes da realidade no interior de uma narrativa. (CAMUS, 2011, p. 289-319)
} 

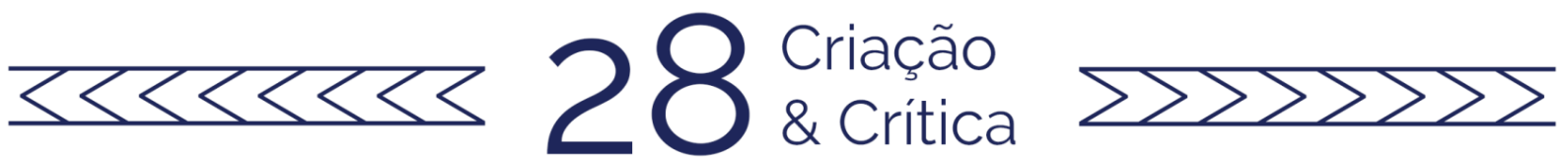

faltou: passados mais de 70 anos de sua viagem, o encontro de Camus com o Brasil ainda é relembrado e celebrado pelas novas gerações de leitores brasileiros que se encontram com a obra do escritor ${ }^{68}$.

\section{Referências bibliográficas}

ANDREU, Jean-Louis. "Un rendez-vous manqué : le voyage d'Albert Camus en Amérique du Sud (1949)". Caravelle, n58, 1992. L'image de l'Amérique latine en France depuis cinq cents ans.

ARAUJO, Laís Corrêa de. Murilo Mendes, ensaio crítico, antologia, correspondência. São Paulo: Editora Perspectiva, 2000.

BANDEIRA, Manuel. "Recordação de Albert Camus" Seleta de Prosa Rio de Janeiro: Nova Fronteira, 1997.

BARBIERI, Cassio Guilherme. "O filósofo do absurdo nos trópicos: a recepção inicial da obra de Albert Camus no Brasil a partir dos periódicos nacionais da década de 1940", Trabalho de conclusão de curso, 2017, UFFS.

BARTFELD, Fernande Albert Camus, voyageur et conférencier, le voyage en Amérique du Sud Paris : Lettres Modernes, 1995.

BICALHO, Ana Maria Graciliano Ramos, Valerie Rumjanek e o processo de (re)criação

em "La Peste" de Albert Camus Dissertação de Mestrado, Universidade Federal da Bahia, 2007.

BONNARD, Abel. Océan et Brésil Paris: Flammarion, 1929.

CAMUS, Albert CEuvres Complètes, Bibliothèque de la Pléiade t. I, Paris: Gallimard, 2006.

CEuvres Complètes, Bibliothèque de la Pléiade t. III, Paris: Gallimard,

2008a.

CEuvres Complètes, Bibliothèque de la Pléiade, t. IV. Paris: Gallimard,

2008.

Essais, Bibliothèque de la Pléiade, Paris: Gallimard, 1997.

Diário de Viagem Trad. Valerie Rumjanek Rio de Janeiro: Record, 2004.

O exílio e o reino Trad. Valerie Rumjanek Rio de Janeiro: Record, 1997.

CHAR, René Correspondance 1946-1959 Paris: Gallimard, 2010.

GRENIER, Jean Correspondance 1932-1960 Paris: Gallimard 1981.

CAMUS, Catherine. Albert Camus Solitarie, solidaire Paris: Gallimard, 2010.

. Albert Camus, le monde en partage Paris: Gallimard, 2013.

\footnotetext{
${ }^{68}$ Cf. a exposição organizada em 2013 "O país da desmedida: Albert Camus no Brasil" exposta no Centro cultural Maria Antonia da qual participamos, juntamente com outros colegas - em especial, Raphael Araújo empreendendo a pesquisa documental na qual se baseou. $E$, mais recentemente, a exposição "Albert Camus um estrangeiro no Brasil" na Casa das Rosas acompanhada da publicação do livro "Albert Camus, o viajante", em 2019, pela Editora Record.
} 

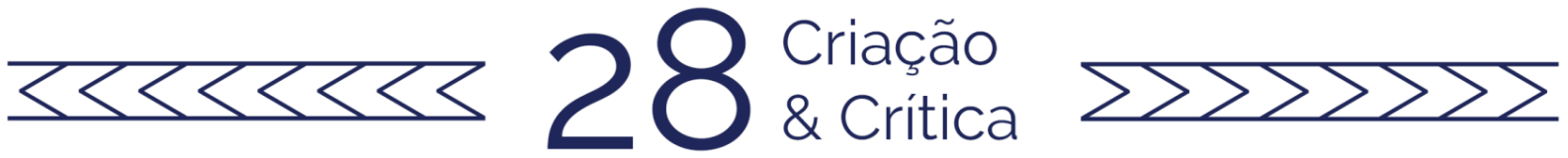

CARDOSO, Luiz Claudio; MARTINIERE, Guy (org.) France-Brésil, vingts ans de coopération (Science et technologie) Éditions de l'IHEAL, 1989.

CARELLI, Mario. Cultures croisées. Histoire des échanges culturels entre la France et le Brésil de la découverte aux temps modernes Paris: Nathan, 1993.

CARELLI, Mario. "Quand les écrivains brésiliens se confiaient à Bernanos". Caravelle, n57, 1991.

CARPAUX, Otto Maria. "Albert Camus no Rio de Janeiro". Província de São Pedro, Letras Estrangeiras 1951.

DA COSTA, Lamartine P. "Intelectuais franceses e brasileiros : verso e reverso". Caravelle, $n^{\circ} 57,1991$.

FEBVRE, Lucien. "O homem do século XVI" Conferência Revista de História, vol. 1, n. 1 (1950) Disponível em: http://www.revistas.usp.br/revhistoria/article/view/34815/37553 Consultado dia 10 de julho de 2019.

GUIMARAES, Júlio Castañon (org.) Cartas de Murilo Mendes a correspondentes europeus Rio de Janeiro: Fundação Casa de Rui Barbosa, 2012.

PEREIRA, Lúcia Miguel. O século de Camus Editora Graphia: Rio de Janeiro, 2015.

PEREIRA, Márcio Rodrigues“Accord culturel entre la France et le Brésil” Le Théâtre

Français au Brésil Un outil de la diplomatie française contre le recul de son influence culturelle, Paris: L'Harmattan, 2009.

MAUROIS, André. Journal d'un tour en Amérique Latine. Editions du bateau ivre, 1948.

MENDES, Murilo. Retratos-Relâmpagos, Poesia completa e prosa, Rio de Janeiro: Nova Aguilar, 1994.

RICOEUR, Paul Temps et Récit I Paris: Gallimard, 2006.

RESENDE, Otto Lara "O mau humor de Camus" O príncipe e o sabiá São Paulo: Companhia das Letras, 1994.

ROSAL, Eduardo; LUCCHESI, Marco "O universo francês de Murilo Mendes" de Eduardo Disponível em: http://www.abralic.org.br/anais/arquivos/2016_1491264106.pdf Consultado em 20 de julho de 2019.

SCHMIDT, Augusto Frederico. "Albert Camus" Antologia de Prosa Rio de Janeiro: Letras e Artes, 1964.

SAUTHIER, Etienne Combray sous les tropiques : Diffusions, réceptions, appropriations et traductions de l'œuvre de Marcel Proust au Brésil (1913-1960) Tese de doutorado, Paris III, 2014.

STEINER, George. Réelles Présences Paris: Gallimard, 2005.

. "O leitor incomum" trad. Maria Alice Máximo In: Nenhuma Paixão

Desperdiçada Rio de Janeiro: Record, 2001.

. Après Babel Paris: Albin Michel, 1998.

STRAUSS, Claude Lévi Tristes trópicos trad. Rosa Freira d'Aguiar São Paulo: Companhia das Letras, 1996.

SUPPO, Hugo Rogelio La politique culturelle française au Brésil entre les années 19201950. Tese de doutorado, Universidade de Paris III, 1999. 

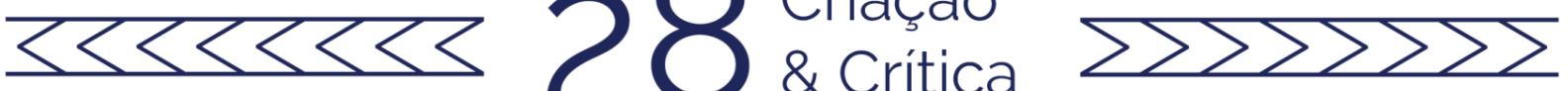

TANASE, Virgil Camus Paris: Gallimard, p.193

TETTAMANZI, Regis "Albert Camus: du Brésil maladif au Brésil fraternel" Les écrivains français et le Brésil. La construction d'un imaginaire de La Jangada à Tristes Tropiques. Paris: L'Harmattan, 2004.

TODD, Olivier Albert Camus, une vie Paris: Gallimard, 1996.

Recebido em: 24/07/2020 Aceito em: 22/08/2020

Referência eletrônica: GESKE, Samara Fernanda A. O. de Lócio e Silva. Dos desencontros ao encontro: a viagem de Albert Camus ao Brasil em 1949. Criação \& Crítica, n. 28, p., dez. 2020. Disponível em: <http://revistas.usp.br/criacaoecritica>. Acesso em: dd mmm. aaaa. 